\title{
The present-day and future impact of $\mathrm{NO}_{\mathrm{x}}$ emissions from subsonic aircraft on the atmosphere in relation to the impact of $\mathrm{NO}_{\mathrm{x}}$ surface sources
}

\author{
P. J. M. Valks ${ }^{1}$, G. J. M. Velders \\ National Institute of Public Health and the Environment, Air Research Laboratory, PO Box 1, 3720 BA Bilthoven, The Netherlands
}

Received: 7 September 1998 / Revised: 7 December 1998 / Accepted: 14 December 1998

\begin{abstract}
The effect of present-day and future $\mathrm{NO}_{\mathrm{x}}$ emissions from aircraft on the $\mathrm{NO}_{\mathrm{x}}$ and ozone concentrations in the atmosphere and the corresponding radiative forcing were studied using a three-dimensional chemistry transport model (CTM) and a radiative model. The effects of the aircraft emissions were compared with the effects of the three most important anthropogenic $\mathrm{NO}_{\mathrm{x}}$ surface sources: road traffic, electricity generation and industrial combustion. From the model results, $\mathrm{NO}_{\mathrm{x}}$ emissions from aircraft are seen to cause an increase in the $\mathrm{NO}_{\mathrm{x}}$ and ozone concentrations in the upper troposphere and lower stratosphere, and a positive radiative forcing. For the reference year 1990, the aircraft emissions result in an increase in the $\mathrm{NO}_{\mathrm{x}}$ concentration at $250 \mathrm{hPa}$ of about $20 \mathrm{ppt}$ in January and $50 \mathrm{ppt}$ in July over the eastern USA, the North Atlantic Flight Corridor and Western Europe, corresponding to a relative increase of about $50 \%$. The maximum increase in the ozone concentrations due to the aircraft emissions is about 3-4 ppb in July over the northern mid-latitudes, corresponding to a relative increase of about $3-4 \%$. The aircraft-induced ozone changes cause a global average radiative forcing of $0.025 \mathrm{~W} / \mathrm{m}^{2}$ in July. According to the ANCAT projection for the year 2015, the aircraft $\mathrm{NO}_{\mathrm{x}}$ emissions in that year will be $90 \%$ higher than in the year 1990. As a consequence of this, the calculated $\mathrm{NO}_{\mathrm{x}}$ perturbation by aircraft emissions increases by about $90 \%$ between 1990 and 2015 , and the ozone perturbation by about $50-70 \%$. The global average radiative forcing due to the aircraftinduced ozone changes increases by about $50 \%$ between 1990 and 2015. In the year 2015, the effects of the aircraft emissions on the ozone burden and radiative forcing are clearly larger than the individual effects of the $\mathrm{NO}_{\mathrm{x}}$ surface sources. Taking chemical conversion in the aircraft plume into account in the CTM explicitly, by means of modified aircraft $\mathrm{NO}_{\mathrm{x}}$ emissions, a signi-
\end{abstract}

Correspondence to: G. J. M. Velders

${ }^{1}$ Present address: Royal Netherlands Meteorological Institute,

P O Box 201, 3730 AE De Bilt, The Netherlands ficant reduction of the aircraft-induced $\mathrm{NO}_{\mathrm{x}}$ and ozone perturbations is realised. The $\mathrm{NO}_{\mathrm{x}}$ perturbation decreases by about $40 \%$ and the ozone perturbation by about $30 \%$ in July over Western Europe, the eastern USA and the North Atlantic Flight Corridor.

Key words. Atmospheric composition and structure (troposphere - composition and chemistry) ·

Meteorology and atmospheric dynamics (radiative processes)

\section{Introduction}

Air traffic has grown extensively during the last decades and is expected to grow further over the next 20 years. During the 1960-1990 period, worldwide aviation travel increased by about $10 \%$ per year. Air travel at present represents about $10 \%$ of the total passenger kilometres travelled using all forms of modern transportation (NASA, 1997). Since air traffic continues to increase faster than other forms of transportation, this percentage is likely to increase. The growth in world air travel is according to industrial forecasts predicted at about $70 \%$ over the next 10 years and $180 \%$ over the next 20 years (Boeing, 1996; Douglas, 1995); this corresponds to an increase of about 5-6\% per year.

The environmental effects of aircraft emissions of trace gases such as carbon dioxide, nitrogen oxides, hydrocarbons and sulphur oxides have been the subject of several studies in recent years (Derwent, 1982; Johnson et al., 1992; Beck et al., 1992; Schumann, 1994; AERONOX, 1995; Veenstra et al., 1995; Kraus et al., 1996; Wauben et al., 1997; Köhler et al., 1997; Stevenson et al., 1997; NASA, 1997; Brasseur et al., 1997; Schumann, 1997). Aircraft emissions on the global scale are relatively low compared with other anthropogenic emission sources. For instance, less than $3 \%$ of the 
anthropogenic $\mathrm{NO}_{\mathrm{x}}\left(=\mathrm{NO}+\mathrm{NO}_{2}\right)$ emissions are due to aircraft. However, the majority of aircraft emissions are released at cruise altitudes (i.e., 9 to $13 \mathrm{~km}$ ), where, with the exception of the $\mathrm{NO}_{\mathrm{x}}$ emissions from lightning, no other sources are present. This part of the atmosphere encompasses both the upper troposphere and the lower stratosphere, where the residence times of trace gases are relatively long and where the emitted trace gases can be transported over large distances before removal. Aircraft emissions may therefore contribute to global scale changes in the atmospheric composition and climate.

This study focused primarily on the present and future effects of aircraft $\mathrm{NO}_{\mathrm{x}}$ emissions, relative to the effect of other anthropogenic surface sources as road traffic, electricity generation and industrial combustion, on the $\mathrm{NO}_{\mathrm{x}}$ and ozone concentrations in the atmosphere, as well as the corresponding radiative forcing. The emissions of $\mathrm{NO}_{\mathrm{x}}$ from air traffic contribute significantly to the $\mathrm{NO}_{\mathrm{x}}$ concentrations in the upper troposphere and the lower stratosphere. Although the direct effect of these emissions on the radiative forcing is negligible (Fortuin et al., 1995; NASA, 1997), $\mathrm{NO}_{\mathrm{x}}$ plays an important role in the ozone chemistry. This leads to an increase of ozone in the upper part of the troposphere and the lower part of the stratosphere, where the sensitivity of radiative forcing to changes in ozone is much greater than near the Earth's surface (Lacis et al., 1990; IPCC, 1996; Wauben et al., 1998). A detailed description of the main chemical processes in the upper troposphere and lower stratosphere that lead to ozone production from aircraft $\mathrm{NO}_{\mathrm{x}}$ emissions can, for instance, be found in AERONOX (1995) and in NASA (1997).

The effects of aircraft and surface (e.g. road traffic) $\mathrm{NO}_{\mathrm{x}}$ emissions on the $\mathrm{NO}_{\mathrm{x}}$ and ozone concentrations in the troposphere and the lower part of the stratosphere have been calculated using a three-dimensional chemistry transport model (CTM) (Zimmermann, 1984, 1988; Thé, 1997). Since global CTMs, like the one used in this study, have relatively coarse grid spatial resolution (hundreds of kilometres), the chemical conversion and dispersion directly behind the aircraft up to grid scale cannot be calculated with the CTM. Therefore, a sensitivity analysis was performed using an aircraft exhaust plume model that translates the aircraft $\mathrm{NO}_{\mathrm{x}}$ emissions into emissions for the CTM. The use of plume calculations in CTMs is a relatively new approach (Meijer et al., 1997; Petry et al., 1998) and not often used in prior aircraft studies. To be able to compare our results with those of prior studies, the aircraft plume parametrization was therefore only applied to a sensitivity analysis, described in Sect. 4.4, and not to the other CTM calculations.

Air traffic is expected to grow further over the next $20 \mathrm{y}$, and although the resulting increase in aircraft emissions is expected to be less due to technically improved engines, the relative importance of aircraft emissions relative to the other anthropogenic $\mathrm{NO}_{\mathrm{x}}$ emission sources is expected to increase. Therefore model calculations were performed not only for the reference year 1990, but also for the 1990-2015 period, based on emission scenarios for aircraft and ground emissions. Furthermore, the effects of aircraft emissions for this period on the ozone concentrations and the radiative forcing were compared with the effects of the three most important anthropogenic $\mathrm{NO}_{\mathrm{x}}$ surface sources at northern mid-latitudes (industrial combustion, electricity generation and road traffic), as calculated using present and predicted future emissions.

\section{Model description}

The chemistry transport model used in this study is the RIVM version of the MOGUNTIA model (Thé, 1997), originally developed by Crutzen and Zimmermann (Crutzen and Gidel, 1983; Zimmermann 1984, 1988; Jacob et al., 1997). The model calculates the monthly averaged distribution of 46 chemical species, including ozone, hydrogen oxides, nitrogen oxides, methane and several non-methane hydrocarbons. Its horizontal resolution is $10^{\circ}$ in latitude and $10^{\circ}$ in longitude. In the vertical, the model has 10 layers reaching from the Earth's surface to the lower stratosphere (50 mbar). In the upper troposphere and lower stratosphere (between 300 and $50 \mathrm{hPa}$ ), the region where most of the aircraft $\mathrm{NO}_{\mathrm{x}}$ emissions take place, the model has four vertical layers. The transport of the species is calculated by using monthly averaged wind fields.

Although the relatively coarse vertical resolution and the use of monthly averaged wind fields in the model restrict its ability to accurately represent the (upper) tropospheric transport and chemistry of trace gases like $\mathrm{NO}_{\mathrm{x}}$ and ozone, this model was adopted because of the short computation time needed for simulating a relatively large number of trace gases, which is of special importance for scenario calculations.

\subsection{Transport}

Transport is explicity taken into account for species whose lifetime is larger than a few hours. The transport of these species is described by the advection-dispersion equation, discretized horizontally according to the QUICKEST numerical scheme. QUICKEST is an explicit third-order-accurate, finite-difference scheme originally described by Leonard (1979), and modified by Ekebjaerg and Justesen (1992) to a flux scheme in two dimensions.

The monthly averaged wind fields are taken from ECMWF data. All mixing processes, except for the monthly averaged circulation and deep convection in thunder clouds are parametrized in a single dispersion coefficient contained in the advection-dispersion equation. Deep convection cannot be described by the advection-dispersion equation and is parametrized as a separate process. The basic concepts used are described by Feichter and Crutzen (1990). A major difference between their approach and the one used in this model is that the statistics are based on the ISCCP cloud data set (Thé, 1997) and not on the sparse statistical data used by Feichter and Crutzen (1990). 


\subsection{Chemistry}

In the model, the continuity equation for chemical species is solved using the two-step method (Verwer, 1994; Spee et al., 1997), specially designed to solve ordinary differential equations (ODEs) from atmospheric chemistry. This method provides rapid convergence with reasonable accuracy in the order of $1 \%$, depending on the stiffness of the equations. The method is based on the second-order backward differentiated equation, commonly used in high-precision implicit solvers, but is instead applied to a straightforward Gauss-Seidel iteration.

The chemical mechanism used in the model is based on a scheme very similar to the EMEP scheme (Simpson, 1992). The chemical mechanism contains 46 species and 95 reactions, of which 16 are photochemical; the heterogeneous reactions of $\mathrm{NO}_{3}$ on sea-salt particles and $\mathrm{N}_{2} \mathrm{O}_{5}$ on sulphate aerosol have also been included in the model. All gas-phase reactions rates are updated according to DeMore et al. (1994). The photolysis rates are derived from calculations by Kanakidou et al. (1991) and Kanakidou and Crutzen (1993). Average daytime photolysis rates are calculated at 15-day intervals from solar zenith angles with a hourly variation. A detailed description of the chemical mechanism used in the model can be found in Valks and Velders (1998).

The dry-deposition rates in the bottom model layer are calculated for 10 species $\left(\mathrm{O}_{3}, \mathrm{NO}_{2}, \mathrm{NO}, \mathrm{NO}_{3}, \mathrm{~N}_{2} \mathrm{O}_{5}\right.$, $\mathrm{H}_{2} \mathrm{O}_{2}, \mathrm{HNO}_{3}, \mathrm{CH}_{3} \mathrm{OOH}, \mathrm{HCHO}$ and PAN) by using fixed deposition velocities, distinguishing between land surface, sea and ice/snow. The wet-deposition rates are calculated for five species $\left(\mathrm{H}_{2} \mathrm{O}_{2}, \mathrm{CH}_{3} \mathrm{OH}, \mathrm{HNO}_{3}\right.$, $\mathrm{CH}_{3} \mathrm{OOH}$ and $\mathrm{HCHO}$ ) from Henry's coefficients, the average rainfall, the vertical distribution of the contribution to rainfall and the cloud water content.

\section{Emission data}

The natural and anthropogenic emission sources of $\mathrm{NO}_{\mathrm{x}}$, methane, $\mathrm{CO}$ and several non-methane hydrocarbons are included in the CTM. The emissions from the various $\mathrm{NO}_{\mathrm{x}}$ sources are of particular interest for the scenario calculations. Apart from being emitted from aircraft, $\mathrm{NO}_{\mathrm{x}}$ is produced by lightning and various anthropogenic and natural surface sources such as biomass burning, industry, ground traffic and soil microbial activity. These surface emissions can also contribute to the $\mathrm{NO}_{\mathrm{x}}$ burden at aircraft cruise altitudes through vertical transport out of the planetary boundary layer. A description of the $\mathrm{NO}_{\mathrm{x}}$ sources are given later. For a description of the methane, $\mathrm{CO}$ and nonmethane hydrocarbon emissions in the CTM, see Valks and Velders (1998).

\subsection{Aircraft emissions}

The aircraft $\mathrm{NO}_{\mathrm{x}}$ emission inventory used in this study was provided by the ANCAT/EC Group (Abatement of
Nuisance Caused by Air Traffic of the Environmental Committee of the European Civil Aviation Conference $($ ECAC)). This inventory consists of the ANCAT version 2 emission estimate (Gardner, 1998) for both scheduled and non-scheduled civil air traffic and an emission estimate that accounts for military traffic, developed by the AEA (Atomic Energy Authority of the United Kingdom). It contains the emission estimates for four months (January/April 1992, and July/October 1991) to account for seasonal variations and is a revised and improved version of the first ANCAT database (Gardner et al., 1997). The calculated total $\mathrm{NO}_{\mathrm{x}}$ emission for the ANCAT-2 database is $0.55 \mathrm{Tg} \mathrm{N} \mathrm{y}^{-1}$, with a fleet average $\mathrm{NO}_{\mathrm{x}}$ emission index of $4.44 \mathrm{~g} \mathrm{~N} \mathrm{~kg}^{-1}$ fuel. The emissions are located mainly at cruise altitudes between 9 and $13 \mathrm{~km}$ and near the surface (from take-off and landing).

The future aircraft $\mathrm{NO}_{\mathrm{x}}$ emissions used in the 1990 2015 scenario study, are estimated from a projection of the aircraft emissions to 2015, also produced by the ANCAT/EC group (Gardner et al., 1998). From the ANCAT-2 emission estimate for 1991/1992 and the projection for 2015 , the aircraft $\mathrm{NO}_{\mathrm{x}}$ emissions between 1990-2015 have been calculated assuming a constant yearly growth. The global total aircraft $\mathrm{NO}_{\mathrm{x}}$ emission for 2005 is estimated at $0.80 \mathrm{Tg} \mathrm{N} \mathrm{y}^{-1}$; this is an increase of about $45 \%$ compared to the $\mathrm{NO}_{\mathrm{x}}$ emission for 1990 . For 2015, the global total aircraft $\mathrm{NO}_{\mathrm{x}}$ emission is estimated at $1.06 \mathrm{Tg} \mathrm{N} \mathrm{y}$, an increase of about $90 \%$ compared to $1991 / 1992$. The relatively largest increases in the aircraft emissions take place over the Pacific Rim (more than 150\%); other areas with large increases are found over Western Europe, the USA and the North Atlantic Flight Corridor (NAFC).

\subsection{Surface emissions}

The $\mathrm{NO}_{\mathrm{x}}$ surface emissions from anthropogenic sources and biomass burnings are based on the EDGAR, version 2 (Emission Database for Global Atmospheric Research) inventory for 1990 (Olivier et al., 1996). The most important anthropogenic $\mathrm{NO}_{\mathrm{x}}$ sources are industrial combustion, electricity generation and road traffic. The emissions from natural sources are based on the detailed inventory of Müller (1992, 1993). The total yearly emissions from the $\mathrm{NO}_{\mathrm{x}}$ surface source are given in Table 1.

The future surface emissions of $\mathrm{NO}_{\mathrm{x}}$, used in the 1990-2015 scenario study, have been derived from the Baseline A emission scenario computed by the IMAGE 2 model (Alcamo et al., 1996), an integrated model designed to simulate the dynamics of the global societybiosphere-climate system (Alcamo, 1994). The Baseline A emission scenario is an intermediate scenario with medium assumptions about population and economic growth, and economic activity. It uses the estimates of population and economic growth from the intermediate IPCC scenario IS92a (IPCC, 1992). The scenario provides the $\mathrm{NO}_{\mathrm{x}}$ emissions for 13 world regions up to 2100 and are used to scale the surface emissions of the 
Table 1. Global $\mathrm{NO}_{\mathrm{x}}$ emissions for 1990 and 2015 based on the EDGAR inventory and the IMAGE Baseline A scenario (for the surface sources), and the ANCAT-2 emission inventory for 1991/ 1992 and the ANCAT projection for 2015 (for the aircraft emissions). The emissions from natural sources (Müller, 1992, 1993) are assumed to be constant over time. The values are in $\mathrm{Tg} \mathrm{N} \mathrm{y}^{-1}$

\begin{tabular}{lcc}
\hline $\mathrm{NO}_{\mathrm{x}}$ & 1990 & 2015 \\
\hline Industrial combustion & 5.5 & 8.5 \\
Electricity generation & 6.3 & 12.8 \\
Road traffic & 9.6 & 12.3 \\
Other & 1.6 & 2.4 \\
Total anthropogenic & 23 & 36 \\
$\quad$ surface sources & 0.55 & 1.06 \\
Aircraft & 8 & 12 \\
Biomass burning & 5 & 5 \\
Soil & 5 & 5 \\
Lightning & & \\
\hline
\end{tabular}

reference year 1990, assuming the same seasonal variation and yielding surface emission fields between 1990 and 2015 that can be used in the CTM calculations.

The global total emissions of the $\mathrm{NO}_{\mathrm{x}}$ surface sources for 2005 and 2015 are given in Table 1. The global total emissions of both anthropogenic sources and biogenic sources will continue to increase between 1990 and 2015. The $\mathrm{NO}_{\mathrm{x}}$ emissions from electricity generation show the largest increase: global emission in 2015 is twice as much as that in 1990. Although the total global emission increases between 1990 and 2015, the changes in the anthropogenic $\mathrm{NO}_{\mathrm{x}}$ emissions differ considerably per region. In general, the emissions in the developing world regions increase intensively during the 1990-2015 period. However, the $\mathrm{NO}_{\mathrm{x}}$ emissions from industrial combustion and road traffic decrease between 1990 and 2005 over Western Europe, the USA and Japan, regions where an important part of the emissions occur. After 2005, the anthropogenic $\mathrm{NO}_{\mathrm{x}}$ surface emissions increase in all regions due to the continued increase in energy consumption and industrial activity. Note that the relative contribution of $\mathrm{NO}_{\mathrm{x}}$ emissions from aircraft to all anthropogenic emissions will increase from $2.4 \%$ in 1990 to about $3 \%$ in 2015.

\subsection{Lightning emissions}

The production of $\mathrm{NO}_{\mathrm{x}}$ following nitrogen fixation by lightning flashes is a significant source of atmospheric $\mathrm{NO}_{\mathrm{x}}$. Of all the $\mathrm{NO}_{\mathrm{x}}$ sources, lightning is especially very uncertain, with a range of estimates extending from 1 to over $100 \mathrm{Tg} \mathrm{N} \mathrm{y}^{-1}$ (Liaw et al., 1990). Gallardo et al. (1993) found it unlikely for the global lightning source strength to be higher than $20 \mathrm{Tg} \mathrm{N} \mathrm{y}^{-1}$; however, two recent studies found best estimates that differ by more than a factor of 5 (Lawrence et al., 1995; Price et al., 1997). Note that these values are much greater than the $\mathrm{NO}_{\mathrm{x}}$ emissions from aircraft. In this study, a three dimensional lightning $\mathrm{NO}_{\mathrm{x}}$ emission distribution, based on the parametrization of Price and Rind (1992), was used. The distribution of lightning is divided into cloud to cloud and cloud to ground, yielding different results over oceans and continents and providing a latitudinal dependence. Vertically, the emissions have been distributed homogeneously between the surface and the cloud-top height, derived from ISCCP satellite data. A lightning production of $5 \mathrm{Tg} \mathrm{N} \mathrm{y}{ }^{-1}$ is assumed based on Kowalczyk and Bauer (1982). The greatest emissions are found over the continents in the tropics in the summer period; emissions over the oceans are small due to the low updraft velocities. The vertical extent of lightning $\mathrm{NO}_{\mathrm{x}}$ sources is highest over the tropics and decreases towards the poles.

\section{Effect of aircraft emissions for the period 1990-2015}

\subsection{Background concentrations of $N O_{x}$ and ozone for 1990}

The background concentration of $\mathrm{NO}_{\mathrm{x}}$ and ozone for the reference year 1990 have been calculated with the CTM, using all $\mathrm{NO}_{\mathrm{x}}$ emissions, including the aircraft emissions. We found that to achieve a quasi-equilibrium, a model run of two years, with a realistic initial distribution of the long-lived species, was sufficient. The results presented and discussed in this section correspond to the second year of the simulation.

The zonally-averaged $\mathrm{NO}_{\mathrm{x}}$ and ozone concentrations for January and July are shown in Fig. 1. Because of the short photochemical lifetime, the concentration of $\mathrm{NO}_{\mathrm{x}}$ shows large spatial variations. The distribution in the boundary layer and the lower troposphere is strongly influenced by the anthropogenic $\mathrm{NO}_{\mathrm{x}}$ emissions from industry and traffic, dominating in the northern midlatitudes. The calculated zonally averaged surface mixing ratios at $50^{\circ} \mathrm{N}$ exceed $0.5 \mathrm{ppbv}$, with the highest concentrations in January as the result of the slightly longer lifetime of $\mathrm{NO}_{\mathrm{x}}$ in winter. The emissions from biomass burning and soil occur predominantly in the extra tropics. The $\mathrm{NO}_{\mathrm{x}}$ concentration in the free, unpolluted, troposphere is merely in the order of 5-20 pptv, as can been seen in the Southern Hemisphere and Arctic. In the upper troposphere and lower stratosphere, the $\mathrm{NO}_{\mathrm{x}}$ concentrations are dominated by the stratospheric flux of nitrogen (mainly in the form of $\mathrm{HNO}_{3}$ ).

The modelled $\mathrm{NO}_{\mathrm{x}}$ distribution shows reasonable agreement with the measurements of STRATOZ III (Drummond et al., 1988; Ehhalt et al., 1992). The main features of the modelled $\mathrm{NO}_{\mathrm{x}}$ distribution described are also observed in these measurements. Furthermore, the measurements show a latitudinal gradient in winter from the North Pole to $40^{\circ} \mathrm{N}$ in both the lower stratosphere and the upper troposphere. This is comparable to the AASE II measurements (Weinheimer et al., 1994). The modelled $\mathrm{NO}_{\mathrm{x}}$ concentrations also show this gradient in winter, with the concentrations in the same range. The main deficiency in the modelled $\mathrm{NO}_{\mathrm{x}}$ distribution is the low mixing ratios in the upper troposphere and lower stratosphere, where values of 300-500 pptv are observed during the STRATOZ III measurements. Other recent measurements (e.g. Emmons et al., 1997; Brunner, 1998) 


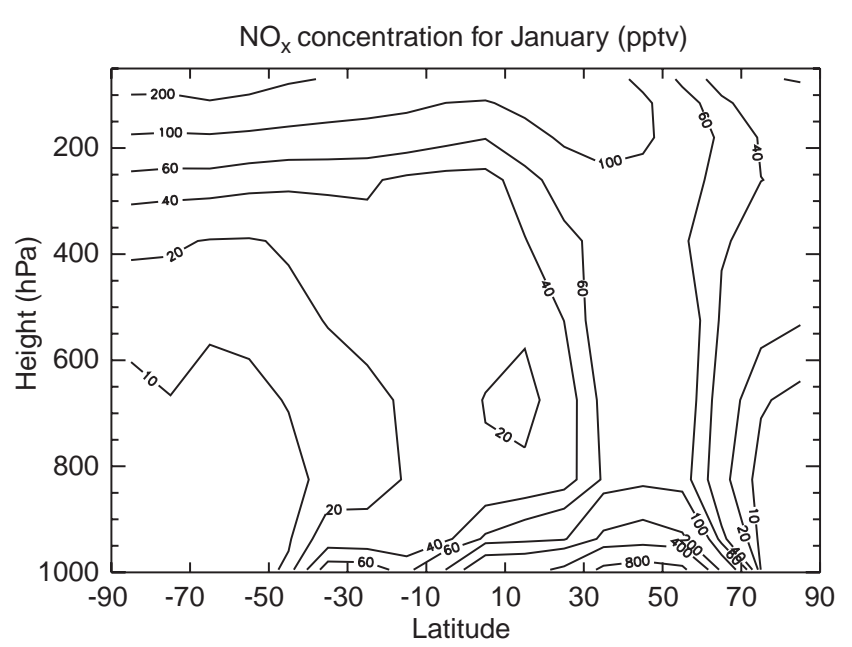

1990
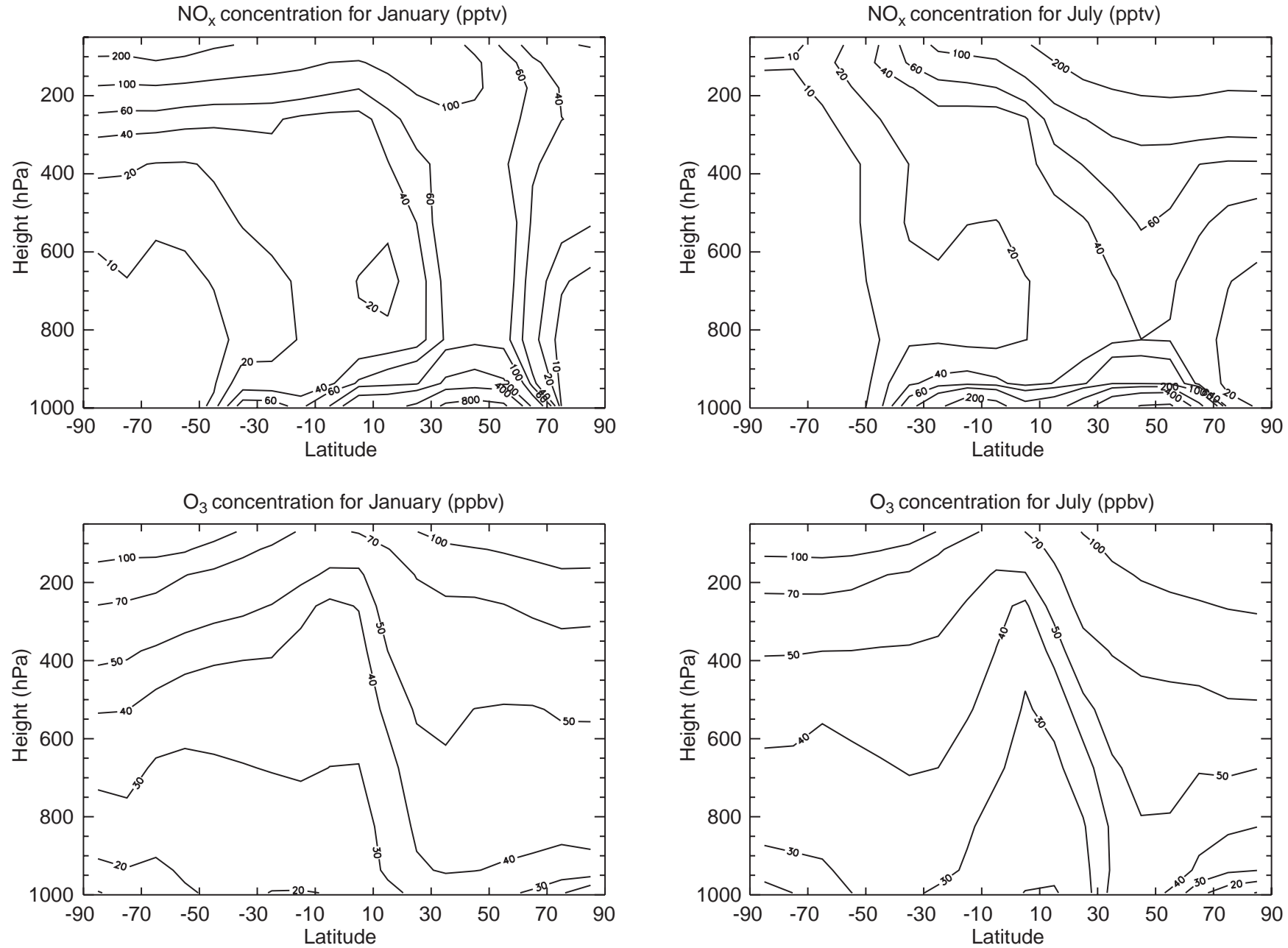

Fig. 1. Zonally-averaged $\mathrm{NO}_{\mathrm{x}}$ (pptv) and $\mathrm{O}_{3}$ (ppbv) background concentrations (including the aircraft emissions) for the reference year 1990 . Figures are for January and July

also show higher $\mathrm{NO}_{\mathrm{x}}$ concentrations in the upper troposphere and lower stratosphere. The modelled $\mathrm{NO}_{\mathrm{x}}$ distribution compare reasonably well with the $\mathrm{NO}_{\mathrm{x}}$ distributions obtained with other models (Müller and Brasseur, 1995; Wauben et al., 1997).

The ozone distribution depends on the (photo)chemical production and destruction, dry deposition and the stratospheric flux of ozone. Since the photochemical production of ozone depends highly on the $\mathrm{NO}_{\mathrm{x}}$ concentration, the ozone concentrations are much higher in the Northern than in the Southern Hemisphere. At the northern mid-latitude boundary layer, the ozone concentrations are greater in July than in January due to more intense radiation and photolysis in summer. Other characteristic features of the ozone distribution are the increased mixing ratio with altitude from the surface to the lower stratosphere, the excursion of low concentrations near the equator towards high altitudes and the dip near $30^{\circ} \mathrm{N}$. These features are also realized using other model computations (Crutzen and Zimmermann, 1991; Müller and Brasseur, 1995; Wauben et al., 1997) and can be seen in observations as well (Kanakidou and Crutzen, 1995). The ozone-mixing ratios in the upper troposphere and lower stratosphere are generally underestimated by the model. It is likely that the coarse vertical resolution of the model in the upper troposphere and lower stratosphere, and the use of monthly average wind fields for the calculation of the advection, contribute to the low ozone concentrations and the small vertical gradient in the upper troposphere and lower stratosphere. Recent tracer studies (Jacob et al., 1997; NASA, 1997) indicate that a vertical resolution of at least $1 \mathrm{~km}$ between 8 and $14 \mathrm{~km}$ altitude may be necessary to resolve the vertical distribution of aircraft emissions and the resulting $\mathrm{NO}_{\mathrm{x}}$ and ozone perturbations.

In Fig. 2, the geographical distributions of the $\mathrm{NO}_{\mathrm{x}}$ and ozone concentrations at $250 \mathrm{hPa}$ are shown for January and July. The geographical distribution at $250 \mathrm{hPa}$ is of particular interest because this is in the range of cruise altitudes $(9-12 \mathrm{~km})$, where an important fraction of the aircraft $\mathrm{NO}_{\mathrm{x}}$ emissions occur. The smallest $\mathrm{NO}_{\mathrm{x}}$ mixing ratios are found over the equatorial regions of the Pacific and Indian Oceans due to the absence of $\mathrm{NO}_{\mathrm{x}}$ sources. The $\mathrm{NO}_{\mathrm{x}}$ concentrations at $250 \mathrm{hPa}$ are higher in summer than in winter. The 
highest concentrations are found in the Northern Hemisphere, with maxima in the eastern USA and in Europe due to the $\mathrm{NO}_{\mathrm{x}}$ emissions from aircraft. The ozone-mixing ratios at $250 \mathrm{hPa}$ are more zonally symmetric compared to the $\mathrm{NO}_{\mathrm{x}}$ mixing ratios due to the longer lifetime of ozone. The low ozone concentrations over the equatorial regions of the Pacific and the Indian Ocean coincide with the local minima for $\mathrm{NO}_{\mathrm{x}}$. At $250 \mathrm{hPa}$, the concentrations generally increase towards the poles, which is in agreement with the variations in the altitude of the tropopause, which is lower near the poles. The highest ozone-mixing ratios are found in the Northern Hemisphere in July due to the higher photochemical production in summer.

\subsection{Perturbation of $\mathrm{NO}_{x}$ and ozone concentrations for 1990}

To calculate the impact of the aircraft $\mathrm{NO}_{\mathrm{x}}$ emissions on the $\mathrm{NO}_{\mathrm{x}}$ and ozone concentrations in the troposphere and lower stratosphere, two model runs have been performed, one with and one without taking the aircraft emissions into account. The difference between the results obtained with and without the aircraft emissions yields the perturbation of the $\mathrm{NO}_{\mathrm{x}}$ and ozone concentrations by aircraft.

The zonally averaged change in the $\mathrm{NO}_{\mathrm{x}}$ concentration due to aircraft emissions for 1990 is shown in Fig. 3 (the difference between the model results obtained with and without the aircraft emissions). As expected, the largest increases in $\mathrm{NO}_{\mathrm{x}}$ occur in the upper troposphere and lower stratosphere at the northern mid-latitudes, where maximum emission occurs. Near $250 \mathrm{hPa}$, the $\mathrm{NO}_{\mathrm{x}}$ perturbation at the northern mid-latitudes is about 10-20 pptv in January and 20-50 pptv in July. The increase in $\mathrm{NO}_{\mathrm{x}}$ is much larger in the Northern Hemisphere than in the Southern Hemisphere and becomes smaller with decreasing altitude. In the lower and middle troposphere, the $\mathrm{NO}_{\mathrm{x}}$ perturbation is generally less than 1 pptv, except that from the northern mid-latitudes. The strong spatial differences in the $\mathrm{NO}_{\mathrm{x}}$ perturbation result from the relatively short lifetime of $\mathrm{NO}_{\mathrm{x}}$, especially in the lower and middle troposphere. Figure 3 also shows the geographical distributions of the $\mathrm{NO}_{\mathrm{x}}$ changes at $250 \mathrm{hPa}$. The largest increases in

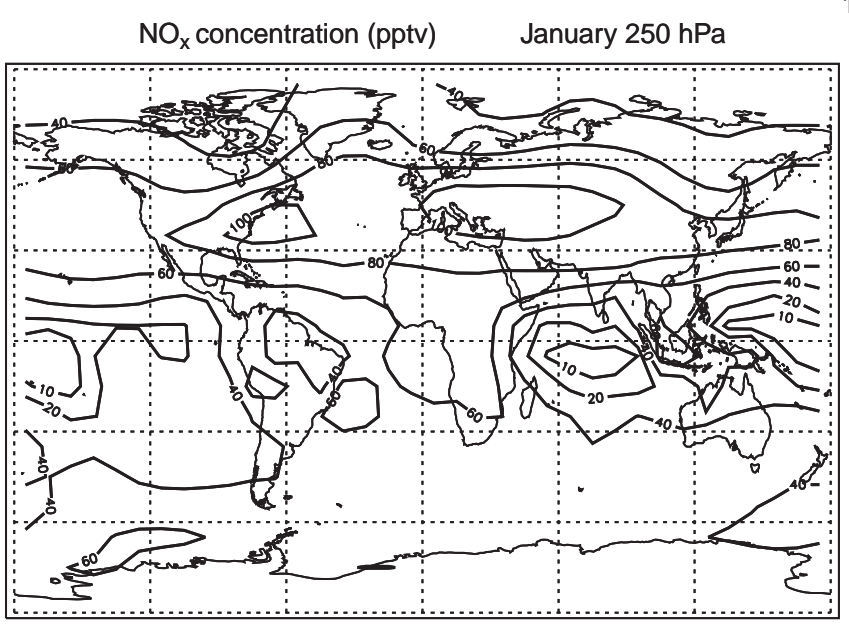

1990
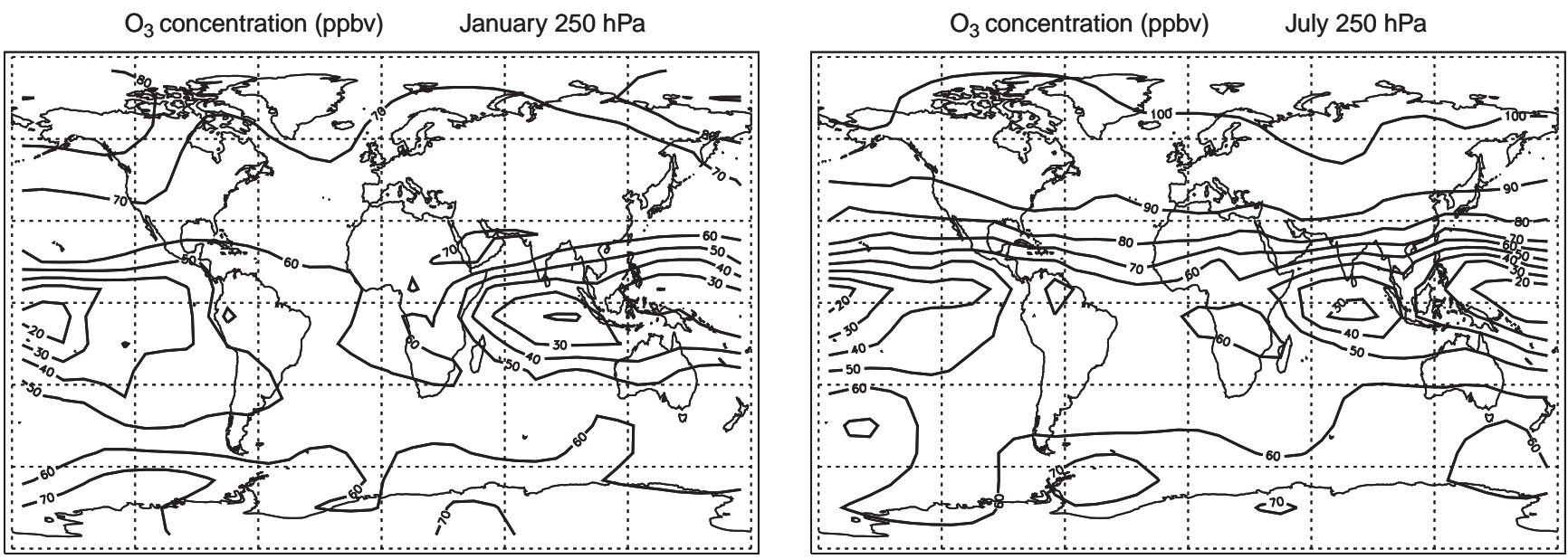

Fig. 2. Distribution of the $\mathrm{NO}_{\mathrm{x}}$ (pptv) and $\mathrm{O}_{3}$ (ppbv) background concentration (including aircraft emissions) at $250 \mathrm{hPa}$ for the reference year 1990. The figures are for January and July 


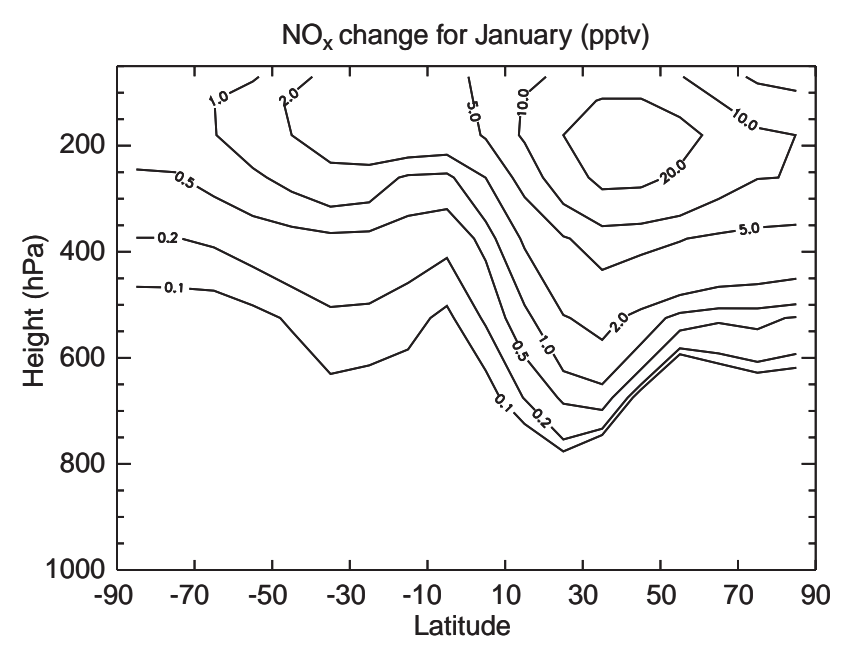

1990
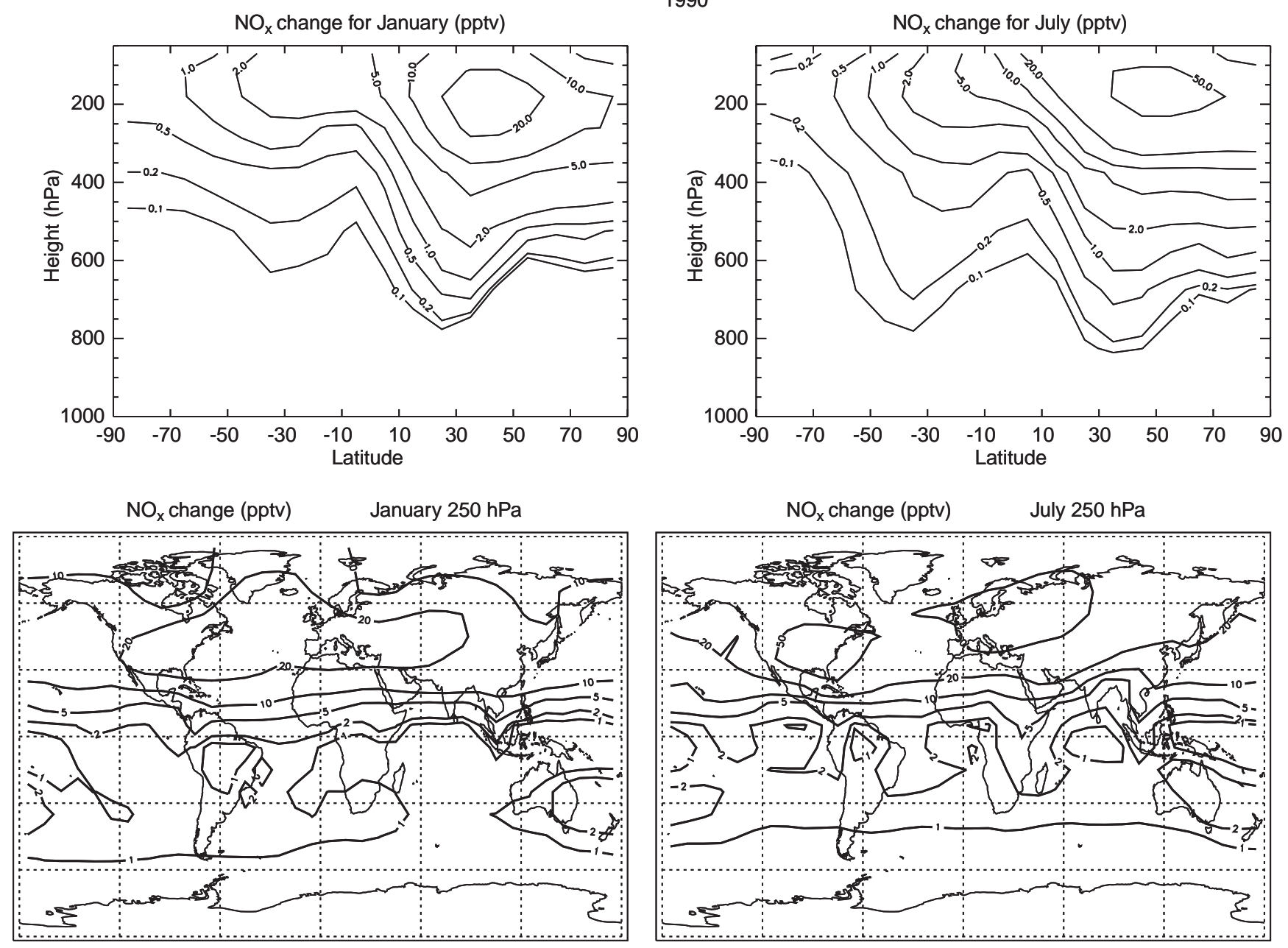

Fig. 3. $\mathrm{NO}_{\mathrm{x}}$ perturbation for January and July due to aircraft emissions for the reference year 1990. Top shows the zonally-averaged $\mathrm{NO}_{\mathrm{x}}$ perturbation (pptv). The lower panels show the distribution of the $\mathrm{NO}_{\mathrm{x}}$ perturbation at $250 \mathrm{hPa}$ (pptv)

$\mathrm{NO}_{\mathrm{x}}$ occur at the northern mid-latitudes: about 20-30 pptv in January (corresponding to a relative increase in the $\mathrm{NO}_{\mathrm{x}}$ concentration of $35-50 \%$ ) and about 45-50 pptv in July over the eastern USA, the North Atlantic Flight Corridor (NAFC) and Europe (corresponding to a relative increase in the $\mathrm{NO}_{\mathrm{x}}$ concentration of about $50 \%$ ). These maxima coincide with the areas where the largest aircraft emissions occur. The $\mathrm{NO}_{\mathrm{x}}$ perturbation is less than 5 pptv in the Southern Hemisphere. This shows that as a result of the relatively short lifetime of $\mathrm{NO}_{\mathrm{x}}$, only a small fraction of the aircraft $\mathrm{NO}_{\mathrm{x}}$ emissions is transported to the Southern Hemisphere.

Figure 4 shows the change in the ozone concentration due to aircraft emissions for 1990. The largest increases in ozone occur in the upper troposphere and lower stratosphere at the northern mid-latitudes, with values of about $1-1.5$ ppbv in January and 2-3 ppbv in July. The ozone perturbation is clearly higher in summer due to the enhanced photochemical activity. The increase in ozone becomes less with decreasing altitude; at the surface in the northern mid-latitude values of about $0.5 \mathrm{ppbv}$ in January and $0.2 \mathrm{ppbv}$ in July are found. In the Southern Hemisphere the ozone pertur- bation is less than $0.5 \mathrm{ppbv}$ in January and $1 \mathrm{ppbv}$ in July and decreases with decreasing altitude. The geographical distribution of the ozone perturbation at $250 \mathrm{hPa}$ is much more zonally symmetric than the $\mathrm{NO}_{\mathrm{x}}$ perturbation, as a result of the longer lifetime of ozone. In January, the maximum perturbation of ozone occurs in a wide band between the northern sub-tropics and mid-latitudes with values of 1.5-2 ppbv (corresponding to a relative increase in the ozone concentrations of $2-3 \%$ ). Due to the enhanced photochemical activity in summer, the perturbation of ozone at the northern sub-tropics and mid-latitudes is higher, with maximum values of more than $3.5 \mathrm{ppbv}$ in an area extending from the eastern USA to Europe (corresponding to a relative increase in the ozone concentrations of $4-5 \%$ ). The increase in ozone is much less in the Southern Hemisphere: the perturbation decreases from about $1.0 \mathrm{ppbv}$ at the equator to less than $0.5 \mathrm{ppbv}$ at the South Pole.

The effects of aircraft $\mathrm{NO}_{\mathrm{x}}$ emissions on the $\mathrm{NO}_{\mathrm{x}}$ and ozone burden from the ground to $150 \mathrm{hPa}$, as well as from 450 to $150 \mathrm{hPa}$ (in parentheses), are listed in Table 2. The average changes are given for the area of 


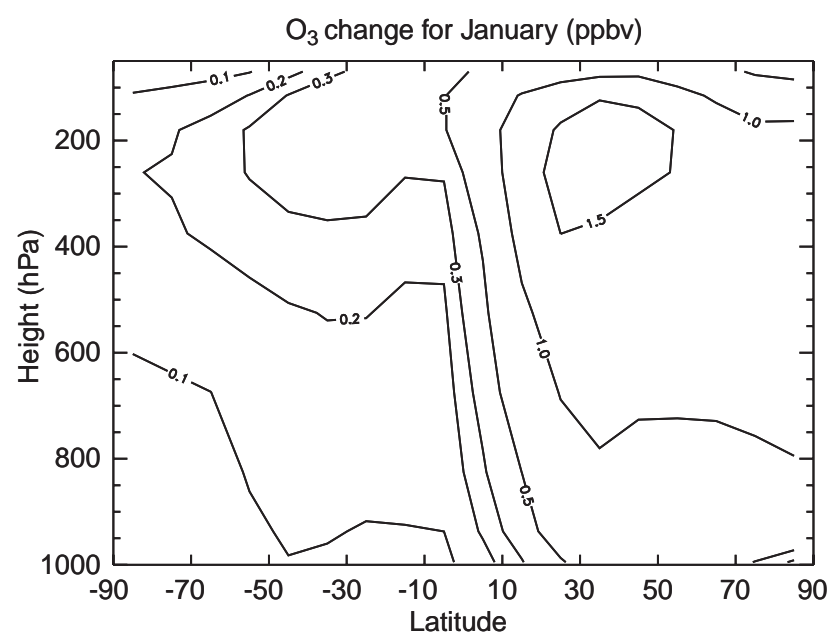

1990
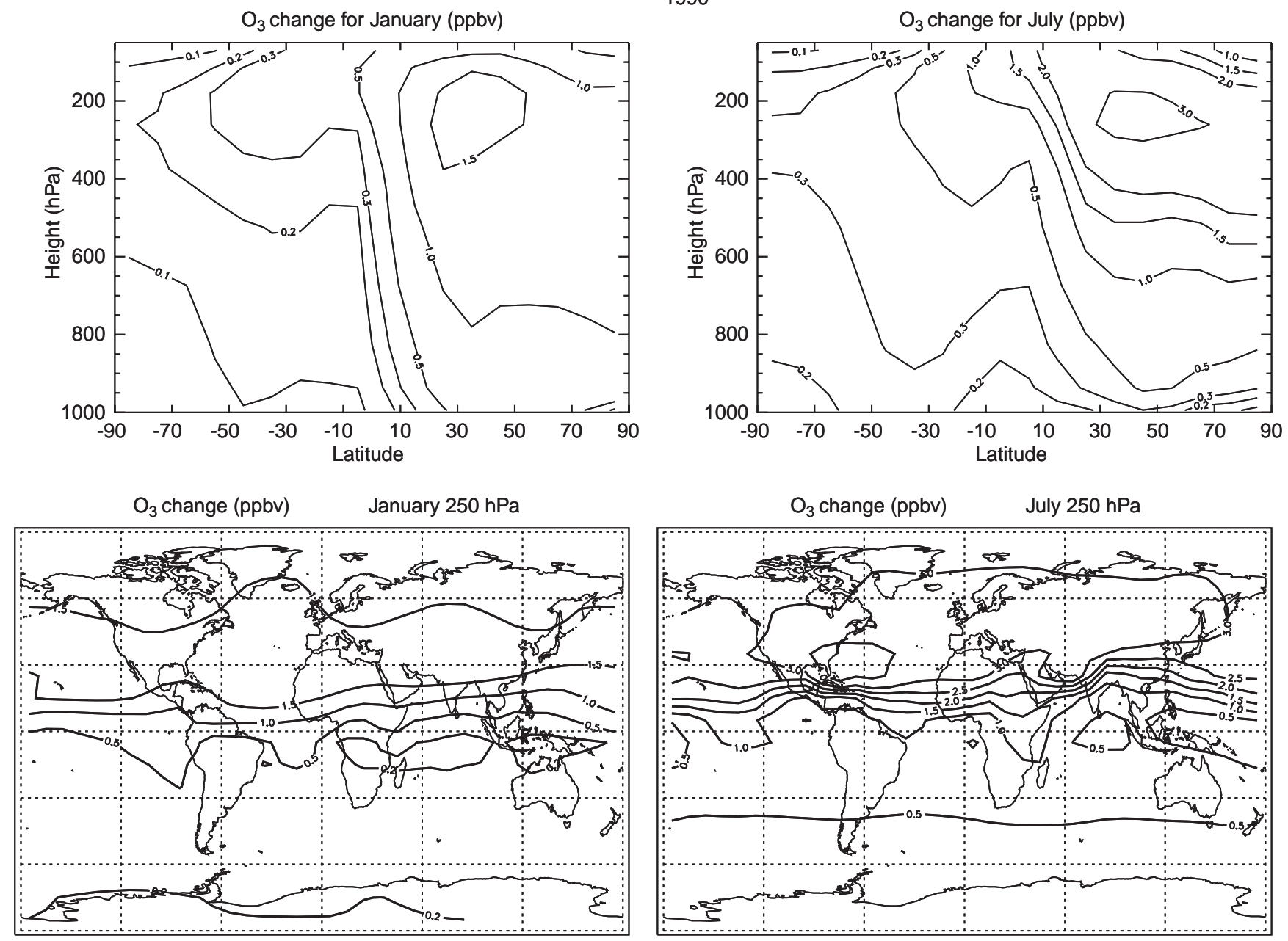

Fig. 4. Ozone perturbation for January and July due to aircraft emissions for the reference year 1990 . Top figures show the zonally-averaged $\mathrm{O}_{3}$ perturbation (ppbv). The lower figures show the distribution of the $\mathrm{O}_{3}$ perturbation at $250 \mathrm{hPa}(\mathrm{ppbv}$ )

Table 2. Changes in the $\mathrm{NO}_{\mathrm{x}}$ and $\mathrm{O}_{3}$ burden (\%) from the ground to $150 \mathrm{hPa}$ and from 450 to $150 \mathrm{hPa}$ (in parentheses) caused by aircraft $\mathrm{NO}_{\mathrm{x}}$ emissions. The average values for $30-60^{\circ} \mathrm{N}$, for the
Northern- and Southern Hemisphere and the global average value are given for January and July for 1990 and 2015

\begin{tabular}{|c|c|c|c|c|c|c|c|c|}
\hline & \multicolumn{4}{|l|}{ January } & \multicolumn{4}{|l|}{ July } \\
\hline & $30-60^{\circ} \mathrm{N}$ & $\mathrm{NH}$ & SH & Global & $30-60^{\circ} \mathrm{N}$ & $\mathrm{NH}$ & SH & Global \\
\hline \multicolumn{9}{|l|}{1990} \\
\hline $\mathrm{NO}_{\mathrm{x}}$ change & $3.9(23.5)$ & 4.3 (18.6) & $1.4(2.4)$ & $3.5(11.3)$ & $10.4(29.5)$ & $9.7(22.7)$ & $2.1(5.4)$ & $7.7(18.6)$ \\
\hline $\mathrm{O}_{3}$ change & $2.3(2.4)$ & $2.1(2.2)$ & $0.6(0.6)$ & $1.4(1.5)$ & $2.5(3.4)$ & $2.4(3.1)$ & $1.0(1.1)$ & $1.7(2.2)$ \\
\hline \multicolumn{9}{|l|}{2015} \\
\hline $\mathrm{NO}_{\mathrm{x}}$ change & $5.4(37.3)$ & $5.8(28.9)$ & $1.7(3.3)$ & $4.8(17.7)$ & $15.1(45.4)$ & $14.1(35.3)$ & $2.7(7.7)$ & $11.0(28.6)$ \\
\hline $\mathrm{O}_{3}$ change & $3.3(3.5)$ & $3.0(3.2)$ & $0.5(0.5)$ & $1.9(2.0)$ & $3.6(4.7)$ & $3.3(4.4)$ & $1.3(1.5)$ & $2.4(3.1)$ \\
\hline
\end{tabular}

$30-60^{\circ} \mathrm{N}$, the Northern and Southern Hemispheres, and the total atmosphere for the months January and July. As expected, the relative changes for $30-60^{\circ} \mathrm{N}$ and for the Northern Hemisphere are much larger than for the Southern Hemisphere, with the largest changes occurring in July. Furthermore, as shown in Table 2, the changes are greatest in the upper troposphere (450$150 \mathrm{hPa}$ ), where maximum aircraft emissions occur. This is especially the case for the change in the $\mathrm{NO}_{\mathrm{x}}$ burden, since the effect of the aircraft emissions on the $\mathrm{NO}_{\mathrm{x}}$ concentration is very small in the lower part of the atmosphere, which contains a large fraction of the total $\mathrm{NO}_{\mathrm{x}}$ burden. For the ozone burden, the difference between the changes from the ground to $150 \mathrm{hPa}$ and from 450 to $150 \mathrm{hPa}$ is less pronounced because of the longer lifetime of ozone and the increasing background concentration of ozone from the ground to the upper troposphere. 
The calculated changes in $\mathrm{NO}_{\mathrm{x}}$ and ozone concentrations due to aircraft emissions for 1990 are generally less than those determined in the AERONOX assessment (AERONOX, 1995) and in the study of Wauben et al. (1997). However, the aircraft emissions used in this study (ANCAT-2 emission database with a total global emission of $0.55 \mathrm{Tg} \mathrm{N} \mathrm{y}^{-1}$ ) are appreciably lower than the ANCAT-1 emissions used in these studies, where total global emission is $0.85 \mathrm{Tg} \mathrm{N} \mathrm{y}^{-1}$. In addition, there is a significant difference in the geographical distributions of the ozone perturbation at $250 \mathrm{hPa}$ in July. The maximum perturbation of ozone calculated with the CTMK model, the KNMI chemistry transport model used in the AERONOX study (see Wauben et al., 1997) is located at the northern polar region, whereas the model results in our study show maximum perturbation of ozone at the northern mid-latitudes. Dameris et al. (1998a) estimated the perturbation of ozone with the three-dimensional dynamic-chemical model ECHAM3/ CHEM using the ANCAT-2 emission database. They found a comparable maximum increase of tropospheric ozone of $3-4 \%$ in the Northern Hemisphere, however, the calculated ECHAM3/CHEM ozone perturbation is independent of season in contrast with the model results in our study. The differences between the ozone perturbations calculated with CTMK and ECHAM3/CHEM models and the model used in this study can be explained by differences in the treatment of transport and chemical processes in the three models.

The perturbations of $\mathrm{NO}_{\mathrm{x}}$ and ozone calculated with the IMAGES model used in the NASA Advanced Subsonic Technology Program (NASA, 1997), where the NASA 1992 emission inventory was used (total global emission of $0.51 \mathrm{Tg} \mathrm{N} \mathrm{y}^{-1}$ ), are fairly similar to the perturbations reported here, with a maximum ozone perturbation found at cruise altitudes at the northern mid-latitudes in July. However, due to the finer vertical resolution in the IMAGES model, the vertical gradients in the $\mathrm{NO}_{\mathrm{x}}$ and ozone perturbation found in the NASA study are larger than in our model results.

\subsection{Perturbation of $\mathrm{NO}_{x}$ and ozone concentrations for 2015}

Since the aircraft $\mathrm{NO}_{\mathrm{x}}$ emissions in 2015 are expected to be $90 \%$ higher than in the reference year 1990 , the $\mathrm{NO}_{\mathrm{x}}$ and ozone perturbations are larger than in 1990. Figure 5 shows the geographical distribution of the $\mathrm{NO}_{\mathrm{x}}$ and ozone perturbation at $250 \mathrm{hPa}$ for 2015. Between 1990 and 2015, the $\mathrm{NO}_{\mathrm{x}}$ perturbation due to the aircraft emissions increases by about $90 \%$. The $\mathrm{NO}_{\mathrm{x}}$ increases in January 2015 exceed 50 pptv in the NAFC and in July 2015 there is a region showing increases of more than 100 pptv and covering a large part of Europe, the NAFC and the eastern USA (corresponding to a relative increase in the $\mathrm{NO}_{\mathrm{x}}$ concentrations of about $100 \%$ ). The ozone perturbation due to the aircraft emissions increases by $50-70 \%$ between 1990 and 2015 . Maximum ozone perturbations of more than $2.5 \mathrm{ppbv}$ are found for January 2015 (corresponding to a relative increase of the ozone concentrations of 3-4\%), while in July the ozone increases are generally more than $5 \mathrm{ppbv}$ north of $30^{\circ} \mathrm{N}$, with a maximum perturbation of 5.5-6 ppbv (corresponding to a relative increase of the ozone concentrations of $5-6 \%$ ). The changes in the $\mathrm{NO}_{\mathrm{x}}$ and ozone burden from the ground to $150 \mathrm{hPa}$ and from 450 to $150 \mathrm{hPa}$ (in parentheses) for 2015 are listed in Table 2. As expected, the changes in the $\mathrm{NO}_{\mathrm{x}}$ and ozone burden increases between 1990 and 2015, with the largest increase in the upper troposphere $(450-150 \mathrm{hPa})$ in July.

The results of this scenario study can be compared with other aircraft scenario studies. Veenstra et al. (1995) have performed scenario studies based on aircraft $\mathrm{NO}_{\mathrm{x}}$ emission scenarios by Olivier (1995) and the IPCC IS92 scenarios (IPCC, 1992) for surface emissions. The future aircraft emissions used in that study are somewhat larger than in the study presented here $\left(0.54 \mathrm{Tg} \mathrm{N} \mathrm{y}^{-1}\right.$ in 1990 and $1.37 \mathrm{Tg} \mathrm{N} \mathrm{y}^{-1}$ in 2015). They calculated the effects of the aircraft emissions using the original MOGUNTIA model and, as a result of the larger aircraft emissions, the changes in the tropospheric ozone burden were somewhat larger than in the study presented here (a yearly average change in the tropospheric ozone burden of $1.6 \%$ in 1990 and $3.4 \%$ in 2015). In the scenario study of Wauben et al. (1995), the same future aircraft emissions were used as in Veenstra et al. (1995), also resulting in somewhat larger changes in the tropospheric ozone burden.

Dameris et al. (1998a, b) have estimated the future impact of sub- and supersonic aircraft $\mathrm{NO}_{\mathrm{x}}$ emissions on ozone with the ECHAM3/CHEM model. They used the NASA emissions scenario for sub- and supersonic air traffic for 2015 (Baughcum and Henderson, 1995) with a total emission of $1.2 \mathrm{Tg} \mathrm{N} \mathrm{y}^{-1}$. The calculated maximum increase in the ozone concentration in the upper troposphere and lower statosphere is much larger than in this study (about 15\%). This could indicate that the ozone increase in the troposphere is significantly influenced by supersonic air traffic as well.

\subsection{Aircraft exhaust plume effects}

Global chemistry transport models have relatively coarse grids (the model used in this study has a horizontal resolution of $10^{\circ} \times 10^{\circ}$ ) and cannot properly take into account processes on smaller spatial scales. For aircraft $\mathrm{NO}_{\mathrm{x}}$ emissions, these sub-grid processes are important since the chemical regime in the plume of an aircraft directly after the exhaust gas emissions differs completely from that of the background atmosphere in which the aircraft flies. For this reason, an aircraft exhaust plume model was developed to study the chemical conversions of aircraft emissions in the plume in the first 24-48 h after the emission occurs (Meijer et al., 1997). This plume model can be used to make parametrizations for global 3D models by converting the exhaust emissions of the engines to effective emissions of the exhaust plume. It includes an up-todate chemical scheme identical to the scheme used in the 


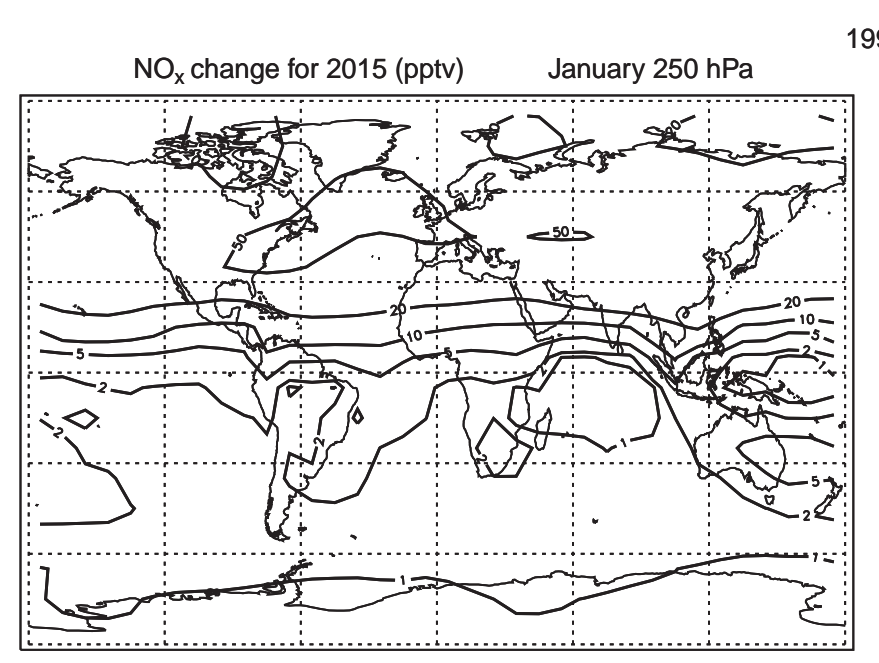

1990
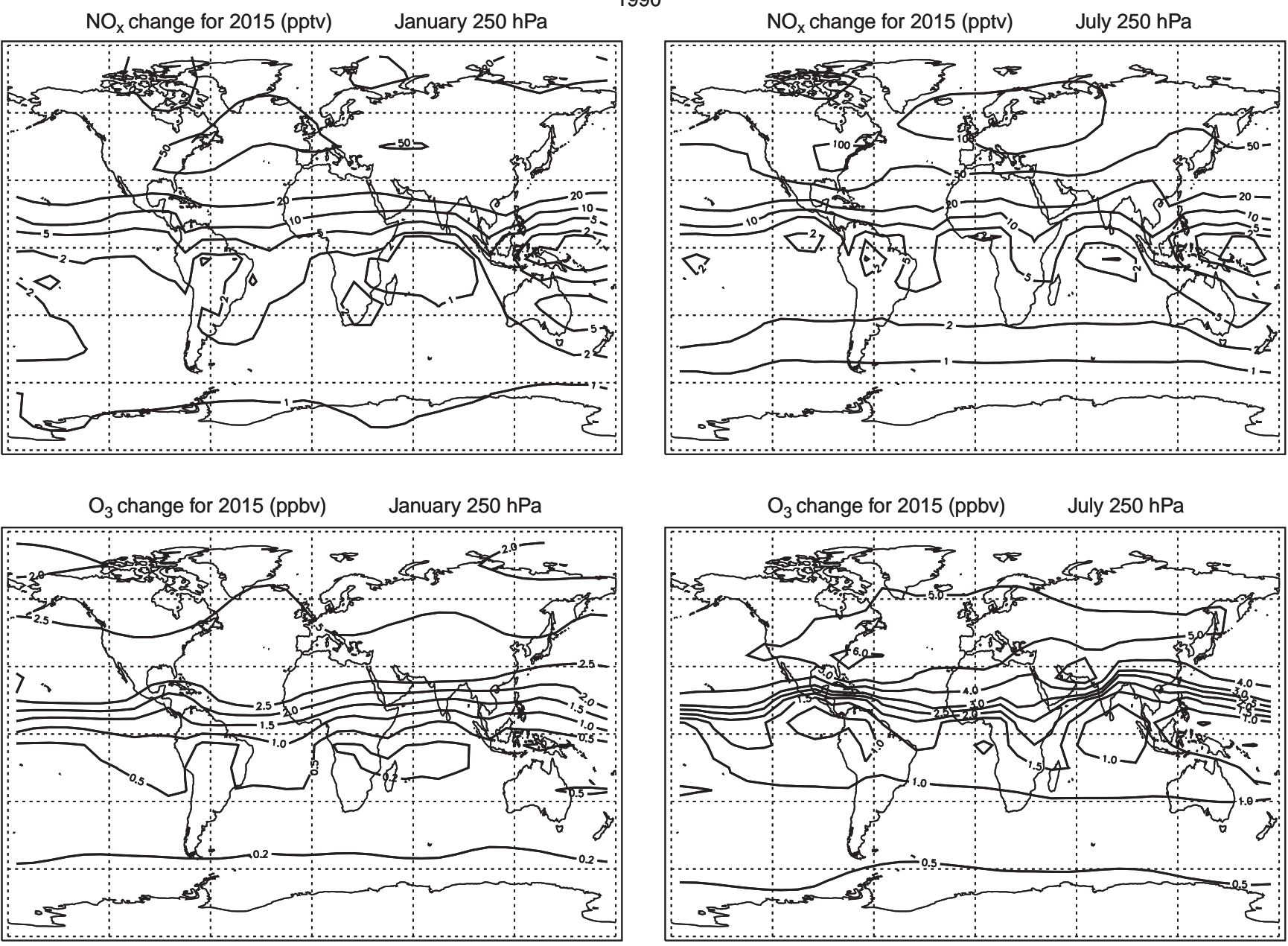

Fig. 5. Distribution of the $\mathrm{NO}_{\mathrm{x}}$ (pptv) and ozone (ppbv) perturbation at $250 \mathrm{hPa}$ due to aircraft emissions for 2015. Figures are for January and July

CTM, with additional heterogeneous reactions and an implementation of the Gaussian elliptic ring structure. A similar method to calculate sub-grid processes in the plume of an aircraft was used by Petry et al. (1998). They used a box model and three different plume models to calculate the chemical conversions of aircraft emissions in the plume, and derived effective emission indices to enable a correction for plume effects in global 3D models.

The calculations with the plume model yield altitude, latitude and season-dependent conversion factors relating the aircraft $\mathrm{NO}_{\mathrm{x}}$ emissions to effective nitrogen oxide emissions of the aircraft plume. These converted emissions do account for the subgrid plume processes and can be used directly in a CTM. The plume model calculations show that the conversion of $\mathrm{NO}_{\mathrm{x}}$ into other nitrogen species depends strongly on temperature and photochemical activity. In summer, $\mathrm{NO}_{\mathrm{x}}$ is much more rapidly converted to $\mathrm{NO}_{y}$ than in winter. In typical summer conditions, the converted nitrogen oxides consist mainly of $\mathrm{HNO}_{3}, \mathrm{HO}_{2} \mathrm{NO}_{2}$ and $\mathrm{N}_{2} \mathrm{O}_{5}$. In typical winter conditions, the main $\mathrm{NO}_{\mathrm{y}}$ fraction is only $\mathrm{N}_{2} \mathrm{O}_{5}$. The formation of other species is suppressed by the low temperatures in winter. The formation of other nitrogen species ( $\mathrm{PAN}, \mathrm{NO}_{3}$ and the organic nitrates) is small and can be neglected as an effective emission product of the aircraft plume.

To calculate the impact of the modified aircraft $\mathrm{NO}_{\mathrm{x}}$ emissions on the $\mathrm{NO}_{\mathrm{x}}$ and ozone concentrations, a CTM run with the effective aircraft emissions of $\mathrm{NO}_{\mathrm{x}}, \mathrm{HNO}_{3}$, $\mathrm{N}_{2} \mathrm{O}_{5}$ and $\mathrm{HO}_{2} \mathrm{NO}_{2}$ has been performed. The results of this model run with modified aircraft emissions was compared to the model run with unmodified aircraft $\mathrm{NO}_{\mathrm{x}}$ emissions to estimate the effect of the chemical processes in aircraft plumes on the global $\mathrm{NO}_{\mathrm{x}}$ and ozone perturbations. (These modified aircraft emissions are only used in the model calculations of this section, not in the other sections).

The differences between the $\mathrm{NO}_{\mathrm{x}}$ and ozone perturbation at $250 \mathrm{hPa}$ of the run with modified and unmodified aircraft emissions are given in Fig. 6 for the reference year 1990. The reduction of the $\mathrm{NO}_{\mathrm{x}}$ perturbation is largest at the northern mid-latitudes, with values between 2 and 5 pptv in January: a relative decrease of $10-20 \%$, compared to the $\mathrm{NO}_{\mathrm{x}}$ perturbation calculated with the unmodified aircraft $\mathrm{NO}_{\mathrm{x}}$ emissions. 

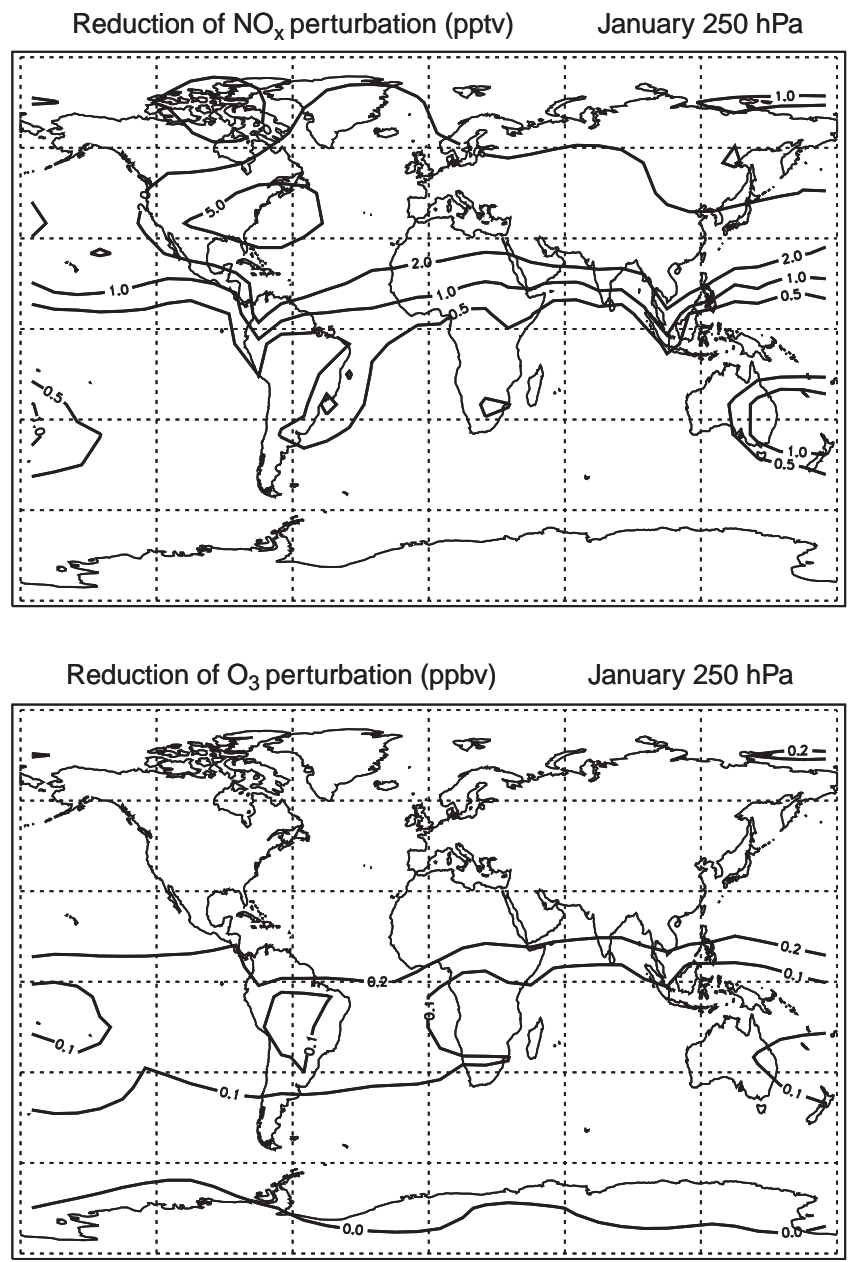

Fig. 6. Difference between the perturbation of $\mathrm{NO}_{\mathrm{x}}(\mathrm{pptv})$ and ozone (ppbv) at $250 \mathrm{hPa}$ due to modified and unmodified aircraft emissions for January and July for the reference year 1990. Positive numbers

In July, a maximum reduction between 10 and 20 pptv is found in Europe, the USA and in the NAFC, corresponding to a relative decrease in the $\mathrm{NO}_{\mathrm{x}}$ perturbation of about $40 \%$. The reduction in the ozone perturbation is about $0.2 \mathrm{ppbv}$ in the northern hemisphere in January, corresponding to a relative decrease of about $15 \%$. In July, the reduction in the ozone perturbation in the Northern Hemisphere is much larger: the maximum reduction is about $1-1.5$ ppbv over southern Europe and the southeast US, corresponding to a relative reduction of about $30 \%$.

Meijer et al. (1997) have used the same modification of the aircraft emissions, according to the plume model simulations, in the KNMI chemistry transport model (CTMK). They found higher absolute reductions of the $\mathrm{NO}_{\mathrm{x}}$ and ozone perturbation due to the use of the modified aircraft emissions than in this study. However, this is to be expected since the $\mathrm{NO}_{\mathrm{x}}$ and ozone perturbations Meijer et al. (1997) have calculated with the unmodified aircraft emissions are also larger. The relative reductions of $\mathrm{NO}_{\mathrm{x}}$ and ozone perturbation in
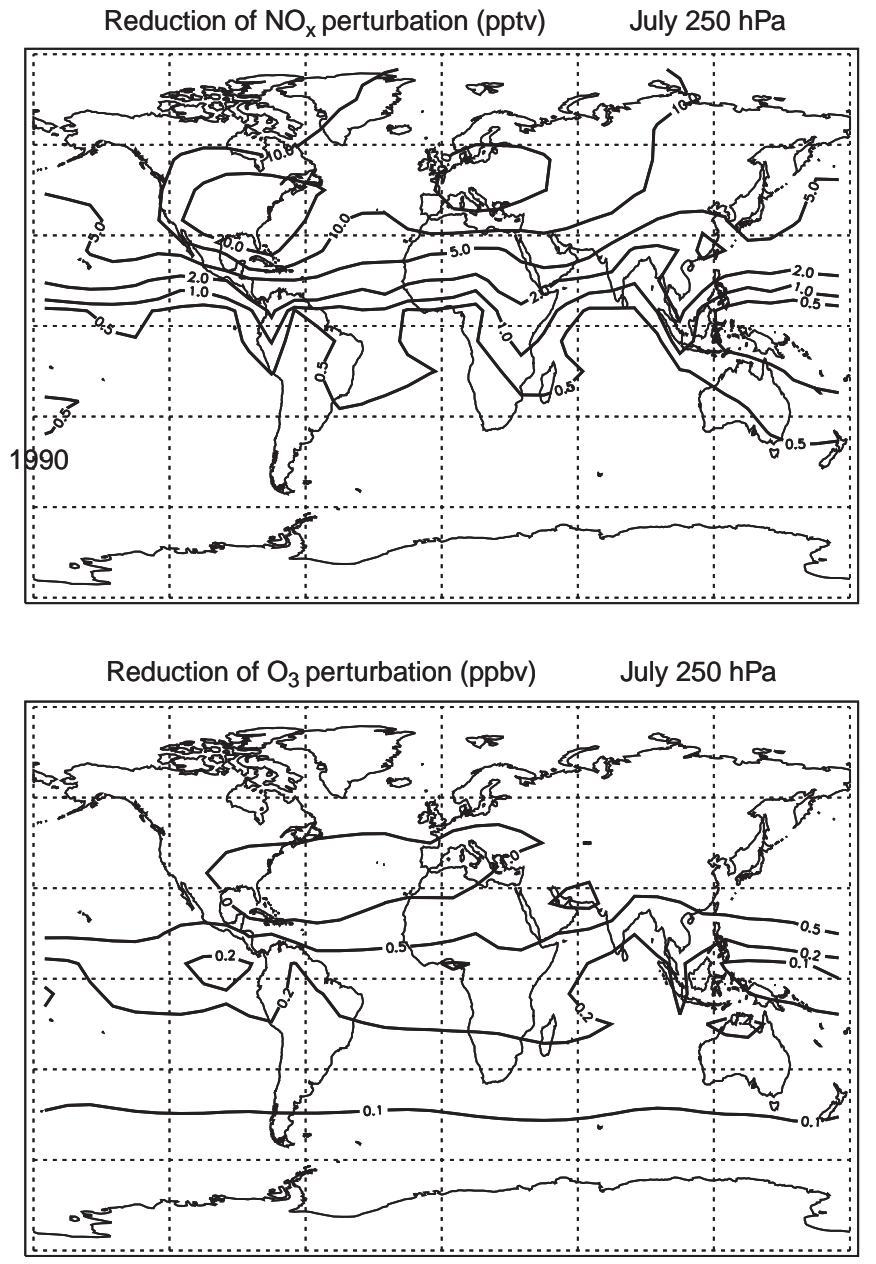

indicate that the use of modified aircraft emissions lead to a reduction of the $\mathrm{NO}_{\mathrm{x}}$ or ozone perturbation

both studies are comparable: Meijer et al. (1997) found a reduction in the $\mathrm{NO}_{\mathrm{x}}$ perturbation in the NAFC of 15$55 \%$ and a reduction in the ozone perturbation of 15 $25 \%$.

\subsection{Effect of anthropogenic $N O_{x}$ surface emissions}

In addition to the calculations of the effects of aircraft emissions, the effects of the three most important anthropogenic $\mathrm{NO}_{\mathrm{x}}$ surface sources at northern midlatitudes (industrial combustion, electricity generation and road traffic) on the ozone concentrations were calculated for the 1990-2015 period. These effects have been calculated in a similar way as the effect of aircraft emissions: the difference between the model results obtained with and without the $\mathrm{NO}_{\mathrm{x}}$ surface source yields the effect on the ozone concentration of this individual surface source. This gives a reasonable approximation of the effect of an individual surface source, however, it should be noted that the total 

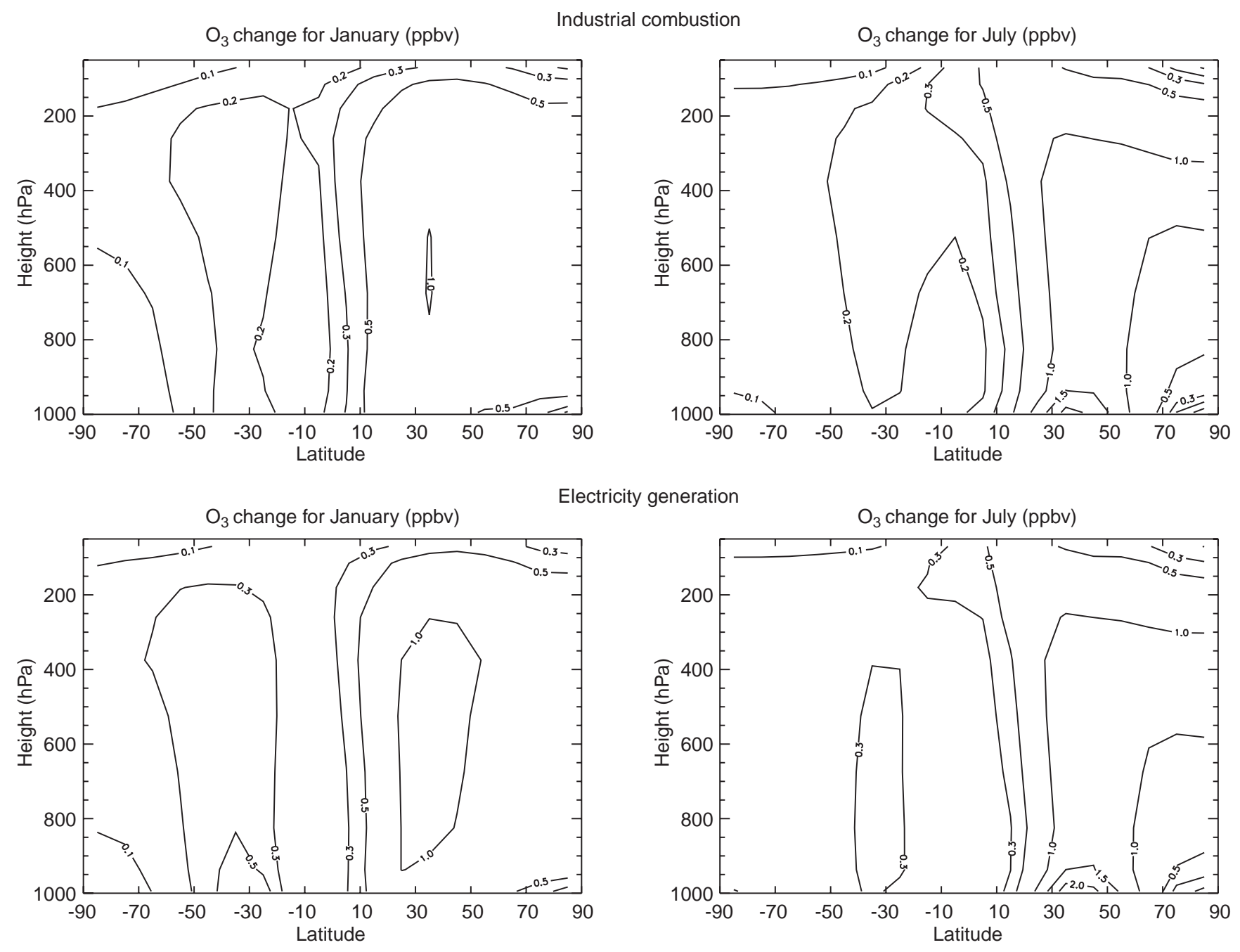

Electricity generation

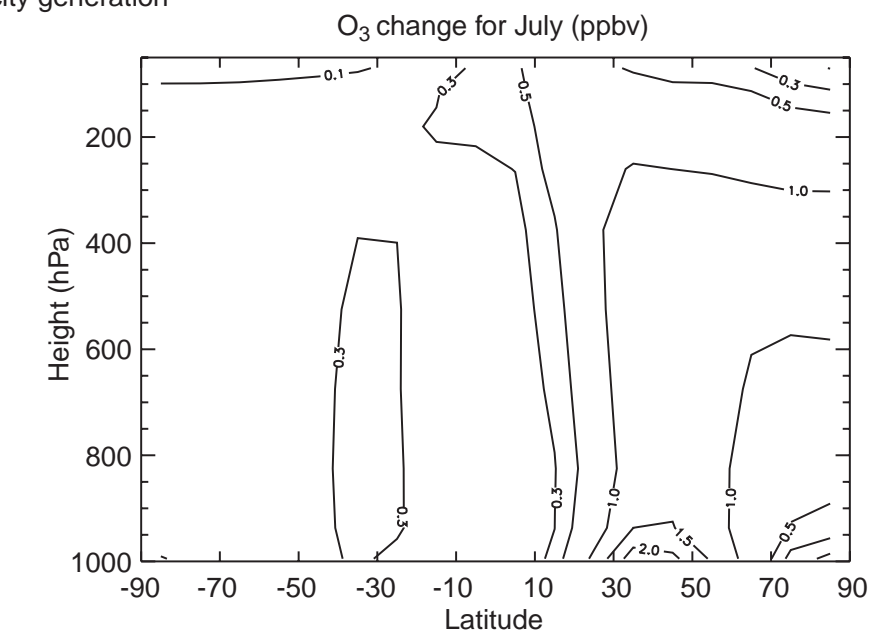

Road traffic

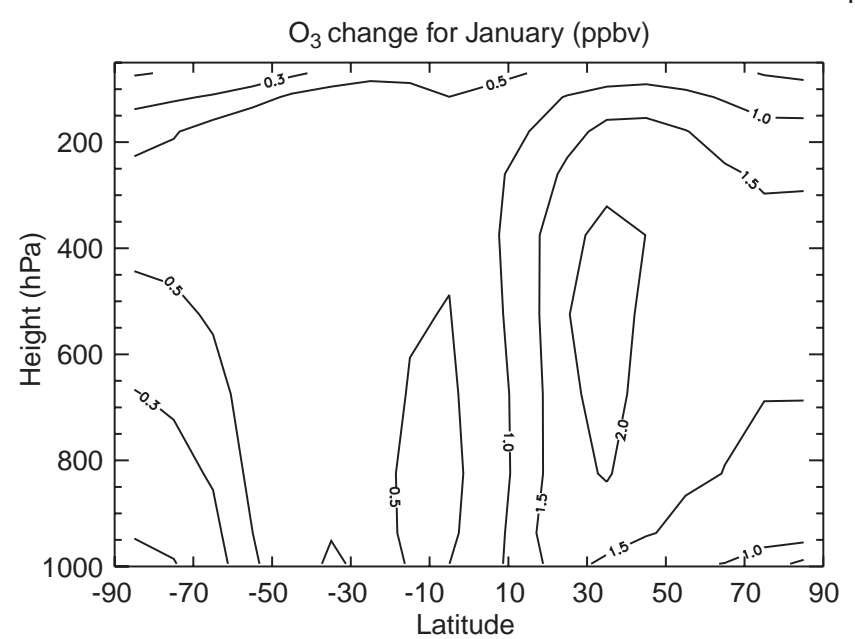

Fig. 7. Contribution of to the $\mathrm{NO}_{\mathrm{x}}$ emissions from industrial combustion, electricity generation and road traffic to the zonallyaveraged ozone concentrations for the year 1990 (the changes in the

contribution of the three surface sources to the ozone changes is larger than the sum of the individual contributions, since the effect of $\mathrm{NO}_{\mathrm{x}}$ emissions on the ozone concentrations is strongly non-linear. (In these

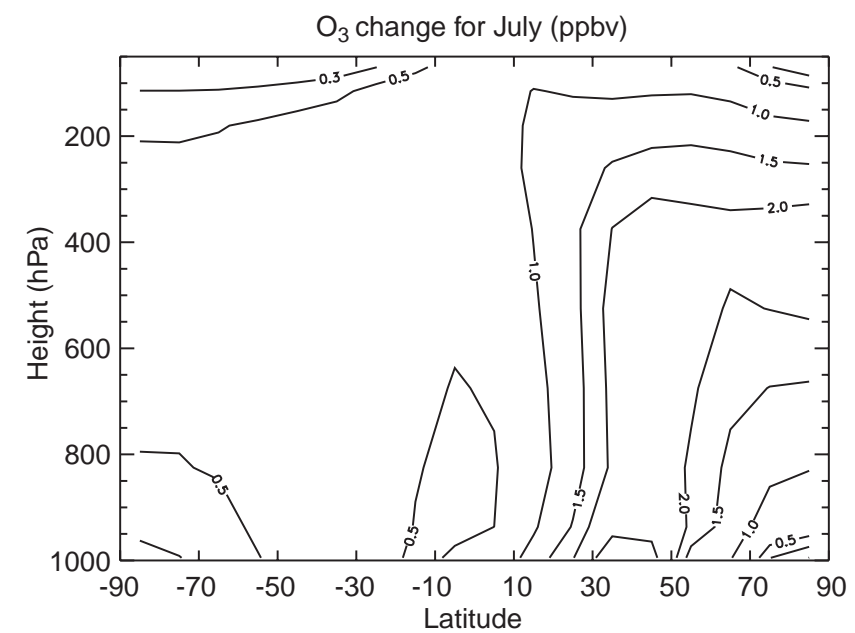

ozone concentration due to aircraft emissions are shown in Fig. 4). Figures are for January and July in ppbv

calculations only the $\mathrm{NO}_{\mathrm{x}}$ sources have been changed, not those of $\mathrm{CH}_{4}, \mathrm{CO}$ and VOC. Therefore these calculations may not be compared with a pre-industrial situation). 
The contributions of these three surface sources to the zonally-averaged ozone concentration are shown for 1990 in Fig. 7. For all three sources, the largest increases (contributions) in ozone occur at the northern midlatitudes, the region with the largest emissions. The ozone increase is clearly higher in July due to the enhanced photochemical activity. The maximum increases in the ozone concentrations are found near the surface, but the increases in the middle and upper troposphere at the northern mid-latitudes are also relatively large. Since road traffic is the most important $\mathrm{NO}_{\mathrm{x}}$ source, the increases in the ozone concentrations due to this source are larger than for the other two sources.

Table 3 lists the contribution of the three anthropogenic $\mathrm{NO}_{\mathrm{x}}$ surface sources to the ozone burden from the ground to $150 \mathrm{hPa}$, and from 450 to $150 \mathrm{hPa}$ (in parentheses), for 1990 and 2015. For comparison, the changes due to the aircraft emissions are also shown here. As expected, the changes in the ozone burden due to the three surface sources from the ground to $150 \mathrm{hPa}$ are larger than for the upper troposphere (450 $150 \mathrm{hPa}$ ); this is because the largest ozone changes occur in the lower and middle troposphere. For 1990, the changes in the ozone burden due to $\mathrm{NO}_{\mathrm{x}}$ emissions from industrial combustion and electricity generation are less than the change due to the aircraft emissions. However, the change in the ozone burden due to $\mathrm{NO}_{\mathrm{x}}$ emissions from road traffic is clearly greater. During the
1990-2015 period, the change in the ozone burden due to electricity generation increases but remains smaller than the change due to the aircraft emissions. The change in the ozone burden due to road traffic and industrial combustion shows a decrease during this period as a consequence of the reduction in these emissions in Western Europe, the USA and Japan; in 2015, the change in the ozone burden due to road traffic is clearly less than the change due to the aircraft emissions.

\section{Radiative forcing}

Aircraft emissions can add to the radiative forcing (IPCC, 1996) through a number of mechanisms which can be divided into direct and indirect effects. Direct effects include the emissions of radiatively active gases and aerosols, such as carbon dioxide and soot particles, and radiative forcing by the ice crystals comprising the contrails in the upper troposphere and lower stratosphere. Indirect effects are related to the ozone changes in response to aircraft $\mathrm{NO}_{\mathrm{x}}$ emissions and alteration of the formation of clouds by aircraft particle emissions. In this study, the analyses are focused on the radiative forcing due to ozone changes. Because the sensitivity of radiative forcing to ozone changes is largest near the tropopause (Wauben et al., 1998), the radiative forcing due to

Table 3. Contribution of the anthropogenic $\mathrm{NO}_{x}$ sources to the $\mathrm{O}_{3}$ burden (\%) from the ground to $150 \mathrm{hPa}$ and from 450 to $150 \mathrm{hPa}$ (in parentheses). The average percentual changes for $30-60^{\circ} \mathrm{N}$, for the Northern- and Southern Hemisphere and the global average are given for 1990 and 2015

\begin{tabular}{|c|c|c|c|c|c|c|c|c|}
\hline & \multicolumn{4}{|l|}{ January } & \multicolumn{4}{|l|}{ July } \\
\hline Aircraft & $2.3(2.4)$ & $2.1(2.2)$ & $0.6(0.6)$ & $1.4(1.5)$ & $2.5(3.4)$ & $2.4(3.1)$ & $1.0(1.1)$ & $1.7(2.2)$ \\
\hline Industry & $1.7(1.3)$ & $1.5(1.2)$ & $0.5(0.4)$ & $1.1(0.8)$ & $2.0(1.3)$ & $1.7(1.2)$ & $0.5(0.4)$ & $1.1(0.9)$ \\
\hline Electricity & $1.9(1.6)$ & $1.7(1.3)$ & $0.8(0.6)$ & $1.3(1.0)$ & $2.1(1.3)$ & $1.7(1.2)$ & $0.6(0.5)$ & $1.2(0.9)$ \\
\hline Road traffic & $3.6(2.9)$ & $3.3(2.6)$ & $1.9(1.5)$ & $2.7(2.1)$ & $3.5(2.1)$ & $3.0(2.0)$ & $1.5(1.3)$ & $2.3(1.7)$ \\
\hline Aircraft & $3.3(3.5)$ & $3.0(3.2)$ & $0.5(0.5)$ & $1.9(2.0)$ & $3.6(4.7)$ & $3.3(4.4)$ & $1.3(1.5)$ & $2.4(3.1)$ \\
\hline Industry & $1.5(1.2)$ & $1.4(1.1)$ & $0.3(0.2)$ & $0.9(0.7)$ & $1.8(1.0)$ & $1.6(1.0)$ & $0.5(0.5)$ & $1.1(0.8)$ \\
\hline Electricity & $3.0(2.4)$ & $2.6(2.0)$ & $0.7(0.4)$ & $1.8(1.3)$ & $3.0(1.6)$ & $2.4(1.4)$ & $0.7(0.6)$ & $1.6(1.1)$ \\
\hline Road traffic & $2.7(2.2)$ & $2.8(2.2)$ & $1.6(1.2)$ & $2.3(1.8)$ & $2.2(0.8)$ & $2.1(1.1)$ & $1.8(1.5)$ & $2.0(1.3)$ \\
\hline
\end{tabular}

Table 4. Contribution to the radiative forcing by ozone changes due to the different anthropogenic $\mathrm{NO}_{\mathrm{x}}$ sources for 1990 and 2015 calculated with the radiation model (MacKay and Khalil, 1991). The average values for the Northern- and Southern Hemisphere and the global average value are given for January and July in $\mathrm{W} \mathrm{m}^{-2}$

\begin{tabular}{|c|c|c|c|c|c|c|}
\hline & \multicolumn{3}{|c|}{ January } & \multicolumn{3}{|l|}{ July } \\
\hline & NH & SH & Global & $\mathrm{NH}$ & SH & Global \\
\hline \multicolumn{7}{|l|}{1990} \\
\hline Aircraft & 0.022 & 0.006 & 0.014 & 0.040 & 0.012 & 0.026 \\
\hline Industry & 0.013 & 0.004 & 0.009 & 0.018 & 0.005 & 0.011 \\
\hline Electricity & 0.015 & 0.006 & 0.011 & 0.018 & 0.006 & 0.012 \\
\hline Road traffic & 0.029 & 0.015 & 0.022 & 0.032 & 0.015 & 0.023 \\
\hline \multicolumn{7}{|l|}{2015} \\
\hline Aircraft & 0.032 & 0.006 & 0.019 & 0.058 & 0.016 & 0.037 \\
\hline Industry & 0.012 & 0.004 & 0.008 & 0.016 & 0.005 & 0.011 \\
\hline Electricity & 0.022 & 0.006 & 0.014 & 0.024 & 0.006 & 0.015 \\
\hline Road traffic & 0.025 & 0.015 & 0.020 & 0.019 & 0.017 & 0.018 \\
\hline
\end{tabular}


aircraft-induced ozone changes can be relatively important. The radiative forcings have been calculated with the radiation model developed by MacKay and Khalil, (1991) using the fixed temperature concept and assuming clear sky conditions. This means that the instantaneous change in net downward irradiance at the tropopause is calculated without taking the indirect influence of changes in temperature and dynamics into account.

Table 4 lists the radiative forcings by the aircraftinduced ozone changes and by the contribution of the three anthropogenic $\mathrm{NO}_{\mathrm{x}}$ surface sources to the ozone concentration for 1990 and 2015. For 1990, the radiative forcing due to $\mathrm{NO}_{\mathrm{x}}$ emissions from industrial combustion and electricity generation is smaller than the radiative forcing due to aircraft $\mathrm{NO}_{\mathrm{x}}$ emissions. The radiative forcing due to $\mathrm{NO}_{\mathrm{x}}$ emissions from road traffic is larger than the radiative forcing due to aircraft emissions for January and somewhat smaller for July. The radiative forcing by the aircraft-induced ozone changes increases by about $50 \%$ between 1990 and 2015 . During this period, the radiative forcing due to the emissions from electricity generation increases as well, while the radiative forcing in the Northern Hemisphere due to industrial combustion and road traffic decreases, due to the decrease in the emissions over Western Europe, the USA and Japan. In 2015, the calculated radiative forcing due to the aircraft emissions is considerably larger than the radiative forcing due to the other anthropogenic $\mathrm{NO}_{\mathrm{x}}$ surface sources.

The radiative forcing by aircraft-induced ozone changes can be compared with the radiative forcing due to the other anthropogenic forcing mechanisms (IPCC, 1995). The total radiative forcing due to changes in greenhouse gas concentrations since pre-industrial times is about $2.45 \mathrm{~W} \mathrm{~m}^{-2}$. This is primarily due to increases in the concentrations of $\mathrm{CO}_{2}\left(1.56 \mathrm{~W} \mathrm{~m}^{-2}\right)$, $\mathrm{CH}_{4}\left(0.47 \mathrm{~W} \mathrm{~m}^{-2}\right)$ and tropospheric ozone. The estimated annually averaged radiative forcing due to tropospheric ozone changes since pre-industrial times is about $0.4 \mathrm{~W} \mathrm{~m}^{-2}$ (Brasseur et al., 1998). Hence, the present-day radiative forcing by aircraft-induced ozone changes is about $1 \%$ of the total radiative forcing and about $7 \%$ of the radiative forcing due to increases in the concentrations of tropospheric ozone. However, it is important to note that the uncertainties in the calculated ozone perturbations and radiative forcing are very large.

\section{Conclusions}

The present and future effects of aircraft $\mathrm{NO}_{\mathrm{x}}$ emissions on the $\mathrm{NO}_{\mathrm{x}}$ and ozone concentrations in the atmosphere and on the radiative forcing have been calculated with a three-dimensional chemistry transport model using the ANCAT-2 aircraft emission inventory and a radiation model. The effects of the aircraft emissions have been compared with the effects of the three most important anthropogenic $\mathrm{NO}_{\mathrm{x}}$ surface sources: road traffic, electricity generation and industrial combustion.

The model results indicate that the present day aircraft $\mathrm{NO}_{\mathrm{x}}$ emissions cause an increase in the $\mathrm{NO}_{\mathrm{x}}$ and ozone concentrations in the upper troposphere and lower stratosphere. Since most $\mathrm{NO}_{\mathrm{x}}$ aircraft emissions occur above the Northern Hemisphere, the increases in the $\mathrm{NO}_{\mathrm{x}}$ and ozone concentrations are much higher in the Northern Hemisphere than in the Southern Hemisphere. For the reference year 1990, the aircraft emissions result in an increase in the $\mathrm{NO}_{\mathrm{x}}$ concentration at $250 \mathrm{hPa}$ of about $20 \mathrm{pptv}$ in January and $50 \mathrm{pptv}$ in July over the eastern USA, the NAFC and Western Europe, corresponding to a relative increase of about $50 \%$. The maximum increase in the ozone concentrations due to the aircraft emissions is about $1.5-2 \mathrm{ppbv}$ in January and 3-4 ppbv in July over the northern mid-latitudes, corresponding to a relative increase of about $2.5 \%$ in January and $3-4 \%$ in July.

According to the ANCAT projection for 2015, the aircraft $\mathrm{NO}_{\mathrm{x}}$ emissions in that year will be $90 \%$ higher than in the reference year 1990. As a consequence of this, the aircraft-induced $\mathrm{NO}_{\mathrm{x}}$ perturbations increase by about $90 \%$ between 1990 and 2015, while the ozone perturbation increases by $50-70 \%$. In 2015 , the aircraft emissions result in an increase in the $\mathrm{NO}_{\mathrm{x}}$ concentration at $250 \mathrm{hPa}$ of about $50 \mathrm{pptv}$ in January and $100 \mathrm{pptv}$ in July over the eastern USA, the NAFC and Western Europe. The maximum increase in the ozone concentrations due to the aircraft emissions is about $2.5 \mathrm{ppbv}$ in January and 5-6 ppbv in July over the northern midlatitudes.

Taking into account chemical conversion in the aircraft plume by means of modified aircraft $\mathrm{NO}_{\mathrm{x}}$ emissions, a significant reduction of the aircraft-induced $\mathrm{NO}_{\mathrm{x}}$ and ozone perturbations results. The $\mathrm{NO}_{\mathrm{x}}$ perturbation decreases by about $40 \%$ and the ozone perturbation by about $30 \%$ in July over Western Europe, the eastern USA and the NAFC.

The effects of the aircraft emissions have been compared with the effects of the anthropogenic $\mathrm{NO}_{\mathrm{x}}$ surface emissions. During the 1990-2015 period, the perturbations due to the aircraft $\mathrm{NO}_{\mathrm{x}}$ emissions increase faster than due to the other $\mathrm{NO}_{\mathrm{x}}$ surface sources. In 2015, the effect of the aircraft emissions on the ozone burden is clearly greater than the effect of the individual $\mathrm{NO}_{\mathrm{x}}$ surface sources, especially in July.

The aircraft-induced ozone changes cause a global average radiative forcing of $0.013 \mathrm{~W} \mathrm{~m}^{-2}$ for January and $0.025 \mathrm{~W} \mathrm{~m}^{-2}$ for July 1990 ; the radiative forcing increases to $0.019 \mathrm{~W} \mathrm{~m}^{-2}$ and $0.037 \mathrm{~W} \mathrm{~m}^{-2}$, respectively, in 2015 , corresponding to an increase of about $50 \%$. In 1990 , the radiative forcing due to $\mathrm{NO}_{\mathrm{x}}$ emissions from road traffic is comparable to the radiative forcing due to aircraft emissions, while the radiative forcing due to $\mathrm{NO}_{\mathrm{x}}$ emissions from industrial combustion and electricity generation is smaller. In 2015, the estimated radiative forcing due to the aircraft emissions is considerably larger than that due to the other anthropogenic $\mathrm{NO}_{\mathrm{x}}$ surface sources, especially in July.

Major uncertainties exist on the representation of various dynamic and chemical processes in CTMs. Furthermore, the coarse vertical resolution and the use of monthly averaged wind fields in the model used in this study restricts its ability to accurately represent the 
(upper) tropospheric transport and chemistry of trace gases like $\mathrm{NO}_{\mathrm{x}}$ and ozone. Although the uncertainties in the calculated changes of the $\mathrm{NO}_{\mathrm{x}}$ and ozone concentrations due to aircraft emissions are large, the model can provide estimates of present and future aircraft perturbations without excessive computation times and in close agreement to those from more complicated models.

Acknowledgements. The research described in this report was carried out as part of the Netherlands AIRFORCE project, representing a coorperative effort of the Royal Netherlands Meteorological Institute (KNMI), the Institute of Marine and Atmospheric Research (IMAU) of the University of Utrecht and the National Institute of Public Health and the Environment (RIVM). The authors gratefully acknowledge P. Zimmermann and P. Crutzen for providing a copy of the chemistry transport model MOGUNTIA, E. Meijer for the plume calculations, J. Olivier for EDGAR emission data, E. Kreileman for IMAGE emission data, and D. Lee and A. Schmitt for ANCAT emission data. The useful comments of P. van Velthoven are also appreciated.

Topical Editor F. Vial thanks P. Perros and another referee for their help in evaluating this paper.

\section{References}

AERONOX The impact of $\mathrm{NO}_{\mathrm{x}}$ emissions from aircraft upon the atmosphere at flight altitudes $8-15 \mathrm{~km}$ Ed. Schumann, U., Report of Sub-Project 3 on Global Atmospheric Model Simulations, EU Project, 1995.

Alcamo, J., Image 2.0: integrated modeling of global climate change, Reprinted from Water, Air, and Soil Pollution, vol. 76, (1-2), 1994. Kluwer Academic Publishers, Dordrecht, The Netherlands, 1994.

Alcamo, J., G. J. J. Kreileman, J. C. Bollen, G. J. van den Born, R. Gerlagh, M. S. Krol, A. M. C. Toet, and H. J. M. de Vries, Baseline scenarios of global environmental change, Global Envir. Change, 6, 261-303, 1996.

Baughcum, S. L., and S. C. Henderson, Aircraft emission inventories projected in year 2015 for a high speed civil transport (HSCT) universal airline network, NASA Contractor Report 4659, Washington, District of Columbia, USA, 1995.

Beck, J. P., C. E. Reeves, F. A. A. M. de Leeuw, and S. A. Penkett, The effect of aircraft emissions on tropospheric ozone in the Northern Hemisphere, Atmos. Env., 26A, 17-29, 1992.

Boeing Commercial Airplane Group 1996 Current Market Outlook, 1996.

Brasseur, G. P., R. A. Cox, D. Hauglustaine, I. Isaksen, J. Lelieveld, D. H. Lister, R. Sausen, U. Schumann, A. Wahner, and P. Wiesen, European Scientific Assessment of The Atmospheric Effects of Aircraft Emissions, European Commission, Science Research Development, Atmos. Env., 32, 2327-2422, 1998.

Brasseur, G. P., J. T. Kiehl, J.-F. Müller, T. Schneider, C. Granier, $X$. Tie, and D. Hauglustaine, Past and future changes in global tropospheric ozone: Impact on radiative forcing, Geophys. Res. Lett., 25, 3807-3810, 1998.

Brunner, D., One-year climatology of nitrogen oxides and ozone in the tropopause region - results from B-747 aircraft measurements, PhD Thesis, 12556, ETH-Zürich, 1998.

Crutzen, P. J., and L. T. Gidel, A two-dimensional photochemical model for the atmosphere. 2. The tropospheric budgets of the anthropogenic chlorocarbons $\mathrm{CO}, \mathrm{CH}_{4}$ and $\mathrm{CH}_{3} \mathrm{Cl}$ and the effect of various $\mathrm{NO}_{\mathrm{x}}$ sources on tropospheric ozone, J. Geophys. Res., D 88, 6641-6661, 1983.

Crutzen, P. J., and Zimmermann P. H, The changing photochemistry of the troposphere, Tellus 43AB, 136-151, 1991.

Dameris, M. V. Grewe, I. Köhler, R. Sausen, C. Brühl, J.-U. Grooß, and $\mathbf{B}$. Steil, Impact of aircraft $\mathrm{NO}_{\mathrm{x}}$ emissions on tropospheric and stratospheric ozone. Part II: 3-D model results, Atmos. Env., 32, 3185-3199, 1998a.

Dameris, M. V. Grewe, R. Hein, C. Schnadt, C. Brühl, and B. Steil, Assessment of the future development of the ozone layer, Geophys. Res. Lett., 25, 3579-3583, 1998b.

DeMore, W. B., S. P. Sander, D. M. Golden, R. F. Hampson, M. J. Kurylo, C. J. Howard, A. R. Ravishankara, C. E. Kolb, and M. J. Molina, Chemical kinetics and photochemical data for use in stratospheric modeling, 1994. Evaluation number 11. JPL-Publications 94-26, Jet Propulsion Laboratory, Pasadena, California, 1994.

Derwent, R. G., Two-dimensional model studies of the impact of aircraft exhaust emissions on tropospheric ozone, Atmos. Env., 16, 1997-2007, 1982.

Douglas Aircraft Company, Outlook for Commercial Aircraft, 19942013, 1995.

Drummond, J. W., D. H. Ehhalt, and A. Volz, Measurements of nitric oxide between $0-12 \mathrm{~km}$ altitude and $67^{\circ} \mathrm{N}$ to $60^{\circ} \mathrm{S}$ latitude obtained during STRATOZ III, J. Geophys. Res., 93, 15 831$15849,1988$.

Ehhalt, D. H., F. Rohrer, and W. Wahner, Sources and distribution of $\mathrm{NO}_{\mathrm{x}}$ in the upper troposphere at Northern Mid-Latitudes, J. Geophys. Res., 97, 3725-3738, 1992.

Ekebjaerg L., and P. Justesen, An explicit scheme for advectiondiffusion modelling in two dimensions, Comput. Methods Appl. Mech. Eng., 88, 287-297, 1992.

Emmons, L. K. et al., Climatologies of $\mathrm{NO}_{\mathrm{x}}$ and $\mathrm{NO}_{\mathrm{y}}$ : a comparison of data and models, Atmos. Env., 31, (12), 18511904, 1997.

Feichter J., and P. J. Crutzen Parametrization of vertical tracer transport due to deep cumulus convection in a global transport model and evaluation with radon measurements, Tellus 42B, 100-117, 1990.

Fortuin J. P. F., R. van Dorland, W. M. F Wauben, and H. Kelder Greenhouse effects of aircraft emissions as calculated by a radiative transfer model, Ann. Geophysicae. Icac 13, 413-418, 1995.

Gallardo, L., H. Rodhe, and P. Crutzen, Evaluation of a global 3-D model of the tropospheric odd nitrogen cycle. Licenciat thesis. Department of Meteorology, Stockholm University, 1993.

Gardner, R. et al., The ANCAT/EC global inventory of $\mathrm{NO}_{\mathrm{x}}$ emissions from aircraft, Atmos. Env., 31, (12), 1751-1766, 1997.

Gardner, R. M., (Ed.) ANCAT/EC2 global aircraft emission inventories for 1991/1992 and 2015: final report produced by the ECAC/ANCAT and EC Working Group. CEC Brussels, Eur No. 18179, ISBN No. 92-828-2914-6, 1998.

IPCC Climate Change 1992: the Supplementary Report to the IPCC Scientific Assessment Eds., J.T. Houghton et al., Cambridge University Press, Cambridge, 1992.

IPCC Climate Change 1995: the Science of Climate Change, Eds., J.T. Houghton et al., Cambridge University Press, Cambridge, 1996.

Jacob, D. J., M. J. Prather, P. J. Rasch, R. L. Shia, Y. J. Balkanski, S. R. Beagley, D. J. Bergmann, W. T. Blackshear, M. Brown, M. Chiba, M. P. Chipperfield, J. Degrandpre, J. E. Dignon, J. Feichter, C. Genthon, W. L. Grose, P. S. Kasibhatla, I. Kohler, M. A. Kritz, K. Law, J.E. Penner, M. Ramonet, C. E. Reeves, D. A. Rotman, D. Z. Stockwell, P. F. J. Vanvelthoven, G. Verver, O. Wild, H. Yang, and P. Zimmermann, Evaluation and intercomparison of global atmospheric transport models using Rn-222 and other short-lived tracers, J. Geophys. Res., D 102, 5953-5970, 1997.

Johnson, C., J. Henshaw, and G. McInnes, Impact of aircraft and surface emissions on nitrogen oxides on tropospheric ozone and global warming, Nature 355, 69-71, 1992.

Kanakidou, M., and P. J. Crutzen, Scale problems in global tropospheric chemistry modeling: comparison of results obtained with a three-dimensional model, adopting longitudinally uniform and varying emissions of $\mathrm{NO}_{\mathrm{x}}$ and $\mathrm{NMHC}$, Chemosphere, 26, 787-801, 1993. 
Kanakidou, M., and P. J. Crutzen, Ozone in the troposphere, in Composition, Chemistry and Climate of the Atmosphere Ed. H.B. Singh Von Nostrand Reinhold, 1995.

Kanakidou, M., H. B. Singh, K. M. Valentin, and P. J. Crutzen, A two-dimensional study of ethane and propane oxidation in the troposphere, J. Geophys. Res., 96, 15 395-15 413, 1991.

Köhler, I., R. Sausen and R. Reinberger, Contributions of aircraft emissions to the atmospheric $\mathrm{NO}_{\mathrm{x}}$ content, Atmos. Env., 31, (12), 1801-1818, 1997.

Kowalczyk, M., and E. Bauer, Lightning as a source of NO in the troposphere, Rep. FAA-EE-82-4, US Department of Transport, Washington DC, 1982.

Kraus, A. B., F. Rohrer, E. S. Grobler, and D. H. Ehhalt, The global tropospheric distribution of $\mathrm{NO}_{\mathrm{x}}$ estimated by a three-dimensional chemical tracer model, J. Geophys. Res., 101, 18 58718604,1996

Lacis, A. A., D. J. Wuebbles, and J. A. Logan, Radiative forcing of climate by changes in the vertical distribution of ozone, J. Geophys. Res., 95, 9971-9981, 1990.

Lawrence, M. G., W. L. Chameides, P. S. Kasibhatla, H. Levy II, and W. Moxim, Lightning and atmospheric chemistry: the rate of atmospheric NO production, in Handbook of Atmospheric Electrodynamics, 1, H. Ed. Volland, 189-202, CRC Press, Boca Raton, Florida, 1995.

Leonard, B. P., A stable and accurate convective modelling procedure based on quadratic upstream interpolation, computer methods, Appl. Mech. Eng., 19, 59-98, 1979.

Liaw, Y. P., D. L. Sisterson, and N. L. Miller, Comparison of field, laboratory, and theoretical estimates of global nitrogen fixation by lightning, J. Geophys. Res., 95, 22 489-22 494, 1990.

MacKay, R. M., and M. A. K. Khalil, Theory and development of a one dimensional time dependent radiative convective climate model, Chemosphere, 22, 383-417, 1991.

Meijer, E. W., P. F. J. van Velthoven, W. M. F. Wauben, J. P. Beck, and G. J. M. Velders, The effect of the conversion of nitrogen oxides in aircraft exhaust plumes in global models, Geophys. Res. Lett., 24, 3013-3016, 1997.

Müller, J.-F., Geographical distribution and seasonal variation of surface emissions and deposition velocities of atmospheric trace gases, J. Geophys. Res., 97, 3787-3804, 1992.

Müller, J.-F., Modelation tri-dimensionelle globale de la chemie et du transport des gaz en trace dans la troposphere, Ph.D Thesis, Belgian Institute for Space Aeronomy, University of Brussels, 1993.

Müller, J.-F., and G. Brasseur, IMAGES: a three-dimensional chemical transport model of the global troposphere, J. Geophys. Res., 100, 16 445-16 490, 1995.

NASA, Atmospheric effects of subsonic aircraft: interim assessment, in Report of the Advanced Subsonic Technology Program, Ed. Friedl, R.R., NASA Reference Publication 1400, 1997.

Olivier, J. G. J., Scenarios for global emissions from air traffic, RIVM Report 773002 003, Bilthoven, The Netherlands, 1995.

Olivier, J. G. J., et al., Description of EDGAR Version 2.0: a set of global emission inventories of greenhouse gases and ozonedepleting substances for all anthropogenic and most natural sources on a per country basis and on $1^{\circ} \times 1^{\circ}$ grid, RIVM Report 771060 002, Bilthoven, The Netherlands, 1996.

Petry, H., J. Hendriks, M. Möllhoff, E. Lippert, A. Meier, A. Ebel, and R. Sausen, Chemical conversion of subsonic aircraft emissions in the dispersing plume: calculation of effective emission indices, J. Geophys. Res., 103, 5759-5772, 1998.
Price, C., and D. Rind, A simple lightning parametrization for calculating global lightning distribution, J. Geophys. Res., 97, 9919-9933, 1992.

Price, C., J. E. Penner, and M. J. Prather, $\mathrm{NO}_{\mathrm{x}}$ from lightning, Part I: global distribution based on lightning physics, J. Geophys. Res., 102, 5929-5941, 1997.

Schumann, U., On the effect of emissions from aircraft engines on the state of the atmosphere, Ann. Geophysicae, 12, 365-384, 1994.

Schumann, U., The impact of nitrogen oxides emissions from aircraft upon the atmosphere at flight altitudes - results from the AERONOX project, Atmos. Env., 31, (12), 1723-1733, 1997.

Simpson, D., Long-period modelling of photochemical oxidants in Europa. Model calculations for July 1985. Atmos. Env., 26A, (9), 1609-1634, 1992.

Spee, E. J., J. G. Verwer, P. M. de Zeeuw, J. G. Blom, and W. H. Hundsdorfer, a numerical study for global atmospheric transport-chemistry problems, Rep. MAS-R9702, CWI Amsterdam, The Netherlands, 1997.

Stevenson, D. S., W. J. Collins, C. E. Johnson, and R. G. Derwent, The impact of aircraft nitrogen oxide emissions on tropospheric ozone studied with a 3D Lagrangian model including fully diurnal chemistry, Atmos. Env., 31, (12), 1837-1850, 1997.

The, T. H. P., Description of a transport chemistry toolbox: a new implementation of Moguntia, RIVM Report 722201 008, Bilthoven, The Netherlands, 1997.

Valks, P. J. M., and G. J. M. Velders, The impact of $\mathrm{NO}_{\mathrm{x}}$ emissions from subsonic aircraft on the atmosphere: a $3 \mathrm{D}$ model study of the changes in ozone and radiative forcing for the period 1990-2015, RIVM Report 728001 007, Bilthoven, The Netherlands, 1998.

Veenstra, D. L., J. P. Beck, T. H. P. The, and J. G. J., Olivier, The impact of aircraft exhaust emissions on the atmosphere; scenario studies with a three dimensional model, RIVM Report 722201 003, Bilthoven, The Netherlands, 1995.

Verwer, J. G., Gauss-Seidel iteration for stiff ODEs from chemical kinetic SIAM J. Sci. Comput., 15, 1243-1250, 1994.

Wauben, W. M. F., P. F. J. van Velthoven, and H. Kelder, Changes in tropospheric $\mathrm{NO}_{\mathrm{x}}$ and $\mathrm{O}_{3}$ due to subsonic aircraft emissions, KNMI Scientific Report; WR 95-04, De Bilt, The Netherlands, 1995.

Wauben, W. M. F., P. F. J. van Velthoven, and H. Kelder, A 3D chemistry transport study of changes in atmospheric ozone due to aircraft $\mathrm{NO}_{\mathrm{x}}$ emissions, Atmos. Env., 31, (12), 1819-1836, 1997.

Wauben, W. M. F., J. P. F. Fortuin, and H. M. Kelder, Sensitivity of radiative forcing due to changes in the global distribution of ozone with application to ozone changes from aviation, Proc. Quadr. Ozone Symp., Aquilla 1996, pp. 827-830, 1998.

Weinheimer, A. J., J. G. Walega, B. A. Ridley, B. L. Gary, D. R. Blake, N. J. Blake, F. S. Rowland, G. W. Rowland, G. W. Sachse, B. E. Anderson and J. E. Collins, Meridional distribution of $\mathrm{NO}_{\mathrm{x}}, \mathrm{NO}_{\mathrm{y}}$, and other species in the lower stratosphere and upper troposphere during AASE II, Geophys. Res. Lett., 21, 2583-2586, 1994.

Zimmermann, P. H., Ein dreidimensionales numerisces Transportmodell für atmosphärische Spurenstoffe, Dissertation, University of Mainz, F.R.G, 1984.

Zimmermann, P. H., Moguntia: a handy global tracer model, in: Van Dop, H. Air Pollution Modeling and its Applications VI. NATO/CCMS, Plenum, New York, 1988. 